\title{
ASSESSMENT OF PHYSICO-CHEMICAL AND BACTERIOLOGICAL QUALITY OF GROUNDWATER AROUND OBOSI DUMP SITE, SOUTHEASTERN NIGERIA
}

\author{
Emereibeole Enos I ${ }^{1}$, Ejike Emmanuel N. $^{2}$, Opara Alexander I. ${ }^{3}$, EbeTochukwu E ${ }^{4}$ \\ ${ }^{1}$ Department of Environmental Management, Federal University of Technology, Owerri, Nigeria. \\ ${ }^{2}$ Department of Chemistry, Federal University of Technology, Owerri, Nigeria. \\ ${ }^{3}$ Department of Geology, Federal University of Technology, Owerri, Nigeria. \\ ${ }^{4}$ Department of Environmental Management, Federal University of Technology, Owerri, Nigeria. \\ http://doi.org/10.35410/IJAEB.2019.4415
}

\begin{abstract}
The assessment of physico-chemical and bacteriological quality of groundwater around Obosi open waste dump in South-eastern Nigeria was investigated. Four leachate and 24groundwater samples from 8 concentric study cells centered at the waste dumpsite were collected and analyzed using experimental method. The heavy metals were determined using Atomic Absorption Spectrophotometer (AAS). The results obtained revealed the mean concentrations of $\mathrm{pH}(5.73 \pm 0.07), \quad$ electrical conductivity $(163.41 \pm 2.99) \mu \mathrm{S} / \mathrm{cm}, \quad \mathrm{DO}(7.93 \pm 0.57)$, $\operatorname{As}(0.01 \pm 0.004) \mathrm{mg} / \mathrm{L}$, lead $(0.48 \pm 0.06) \mathrm{mg} / \mathrm{L}$, iron $(0.55 \pm 0.17) \mathrm{mg} / \mathrm{L}$ and mercury $(0.71 \pm 0.11) \mathrm{mg} / \mathrm{L}$. The presence of microorganisms in some of the water samples within the vicinity of the waste dump indicates groundwater contamination and shows that the leachate generated from the waste dump site could have contaminant risks on boreholes located proximal to the waste dump. It was recommended that a contaminant migration mitigation measure should be performed to reduce the risk of groundwater contamination in the study area.
\end{abstract}

Keywords: Groundwater, waste dump, heavy metals, leachate, South-eastern Nigeria.

\section{INTRODUCTION}

The disposal of Municipal solid waste(MSW)is a global concern, most especially in developing countries across the world, as population growth and high urbanization rates combine with ineffectual and underfunded governments to prevent efficient management of wastes[10,11]. Land filling has been adopted as the simplest, cheapest and most cost effective method of disposing of waste in both developed and developing nations of the world. However, in most developed nations there has been a reduction in the number of landfills as well as the amount of MSW landfilled over the years. The common misconception is that since the materials placed in MSW landfills are basically household wastes, they are relatively "safe" and would not likely affect public health and groundwater quality adversely[18].

Most Nigerian cities such as Onitsha in Anambra State have experienced relatively high rates of urbanization and industrialization. Associated with this urbanization and industrial growth is the influx of people from both local and international reaches, for business and commerce. This has 
created a huge waste burden on the city, as various waste categories, ranging from domestic, through commercial to industrial are deposited at various sites and locations of the town.

The Obosi dumpsite is one of such open waste dumps. Certain pollutants, including toxic substances could be contained in such waste streams[6], and since Obosi is located in the rainforest eco-zone of Nigeria where according to Nigerian Meteorological Agency report in 2014, precipitation could reach as high as $2000 \mathrm{~mm}$ per annum, toxic pollutants such as heavy metals, xenobiotic organic substances, dissolved organic matters and inorganic compounds such as ammonium, calcium, magnesium, sodium, potassium, iron, sulphates and chlorides are leached in the waste streams and migrate through seepage and other physical processes to contaminate groundwater aquifers of the area[15,9].The composition of Leachate primarily depends on the age of the landfill and the degree of waste stabilization. The stabilization of a waste basically proceeds in five sequential or distinct phases[22], and the rate of progress through these stages is a function of the physical (availability of free oxygen), chemical and microbiological conditions developing within the landfill over time[23]. Historically, water bodies have been the attraction for the development of human settlement indicating that water is an essential commodity for life. Due to population explosion, urbanization, heavy industrialization and use of agro-chemicals for agricultural activities, water gets drastically polluted specially groundwater[26, 27].Dissolution of solid waste combined with precipitations produces a large quantity of polluted water in the form of leachate[14]. This leachate greatly affects Groundwater quality[12]. Consequently, this can result to cases of water borne diseases which poses a serious threat to human health[19]. Therefore, this present experimental work is targeted at examining the effect of the Obosi open waste dump on borehole water quality with respect to physicochemical and bacteriological parameters.

\section{MATERIALS AND METHODS}

\subsubsection{The study area:}

Obosi is located on latitude $6.1^{\circ} \mathrm{N}$ and longitude $6.8^{\circ} \mathrm{E}$ in the Anambra North Senatorial Zone of Anambra State, South-eastern Nigeria. It is a suburb of Onitsha metropolis and according to the National Population Commission census figure of 1999, it has a population projection of 256,941 people. The Obosi dumpsite is located between longitude $006^{\circ} 47^{\prime} 59.2^{\prime \prime} \mathrm{E}$ and latitudes $06^{\circ} 06^{\prime}$ $07.8^{\prime \prime} \mathrm{N}$ along the Onitsha-Owerri Express Road, opposite the Metallurgical Training Institute, Onitsha in Anambra State, Nigeria. The waste dumpsite has received wastes streams for over 5 decades and covers an area of about four hectares with an elevation of $40 \mathrm{~m}$. It is surrounded by a stretch of residential buildings. Figure 1.0 shows a section of the Obosi waste dumpsite with sprawling wastes of different categories. 


\section{International Journal of Agriculture, Environment and Bioresearch}

Vol. 4, No. 04; 2019

ISSN: $2456-8643$

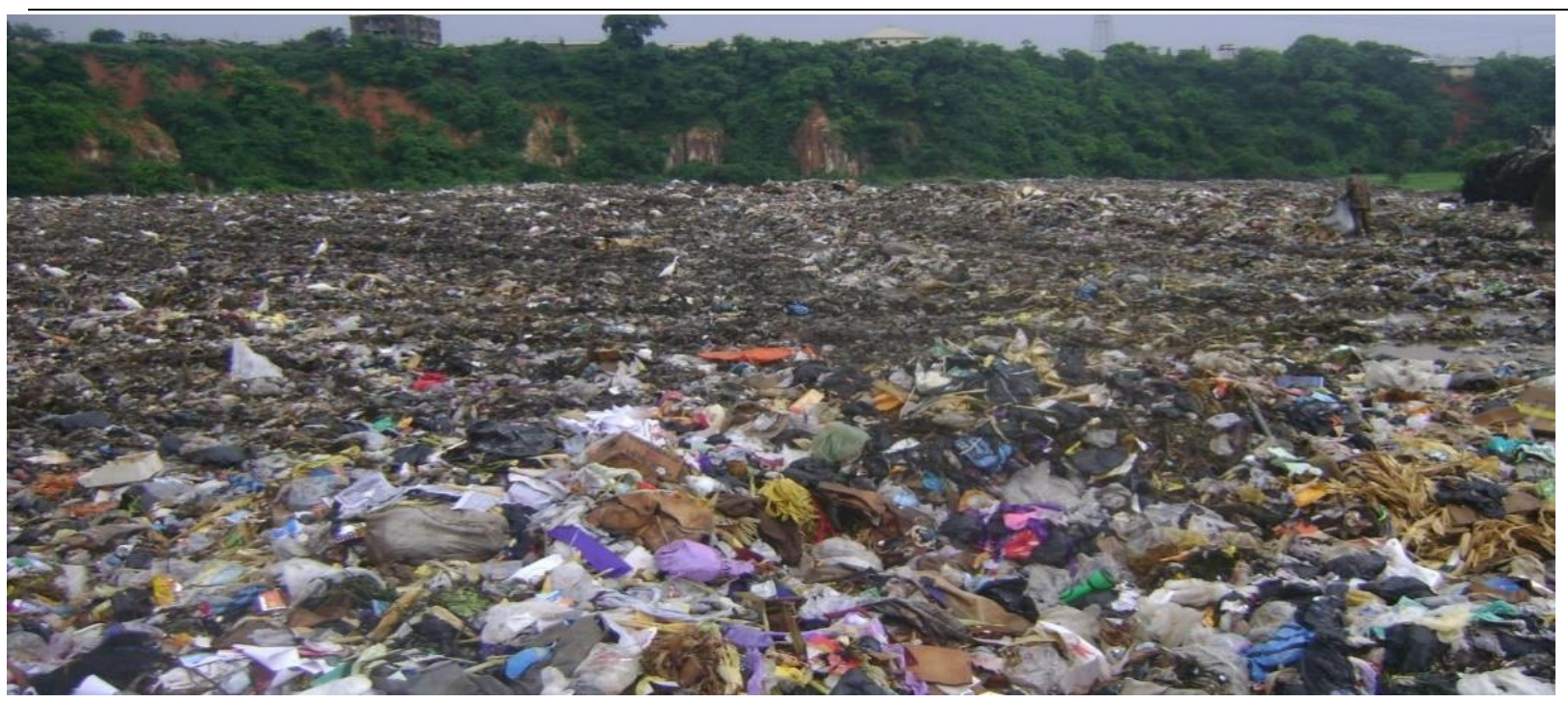

Figure 1.0: A section of the Obosi waste dumpsite showing sprawling wastes of different categories

The depth to groundwater in the area is $34 \mathrm{~m}$. The drainage pattern is generally dendritic as shown in figure 2.0. The area is traversed and drained mainly by the Niger River and its many tributaries, notably

Anambra (which lends the state its name), Nkissi, and Idemili Rivers, all draining into the Niger. The Anambra River is the largest of all the tributaries of the Niger south of Lokoja, the confluence of Benue River with the Niger.

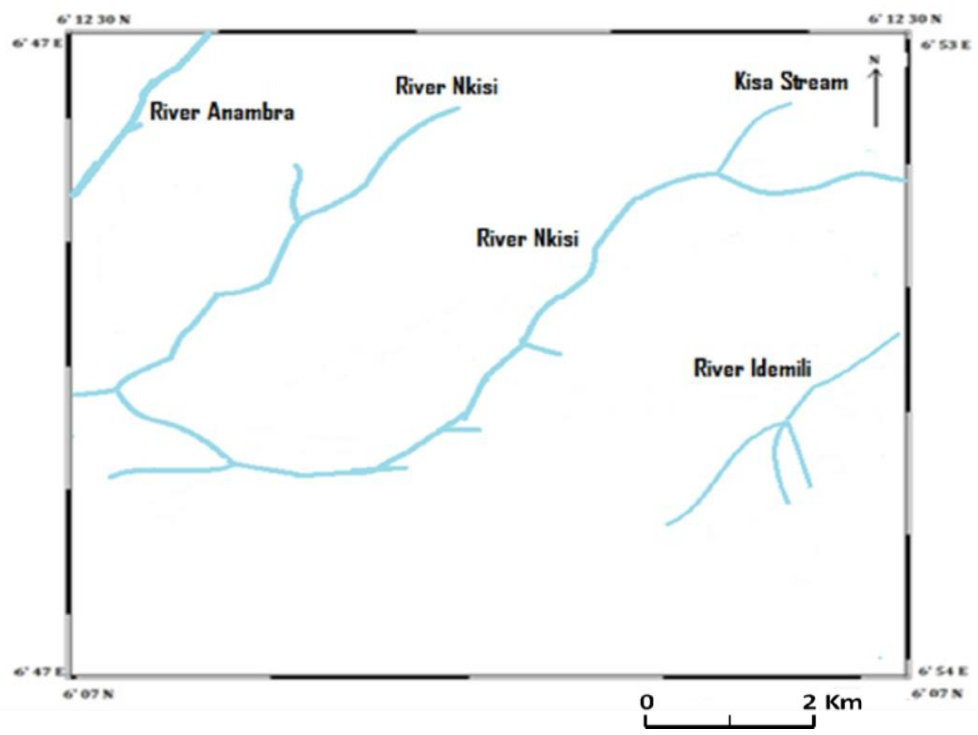

Figure2.0: Drainage map of the study area showing its drainage pattern. 
The geology of the area is characterized by the Orlu cuesta, which terminates at the Niger River bank. This upland area, which varies between 150 and 240metres in height, is dissected by a number of small streams draining into the Niger.

\subsubsection{Sample Collection}

Four leachate and 24 borehole water samples from 8 concentric study cells centered at the waste dumpsite were collected in wet season (June, 2016) of the year. The samples were collected in clean $500 \mathrm{ml}$ screwed plastic bottles, with the use of $\mathrm{HNO} 3$ acid in dilution. They were stored in a temperature of between $4^{\circ} \mathrm{C}$ and $5^{\circ} \mathrm{C}$. During sampling, bottles were thoroughly rinsed thrice with the water to be sampled. The sampling points shown in Figure 3.0 were geo-referenced using Global Positioning System (GPS).

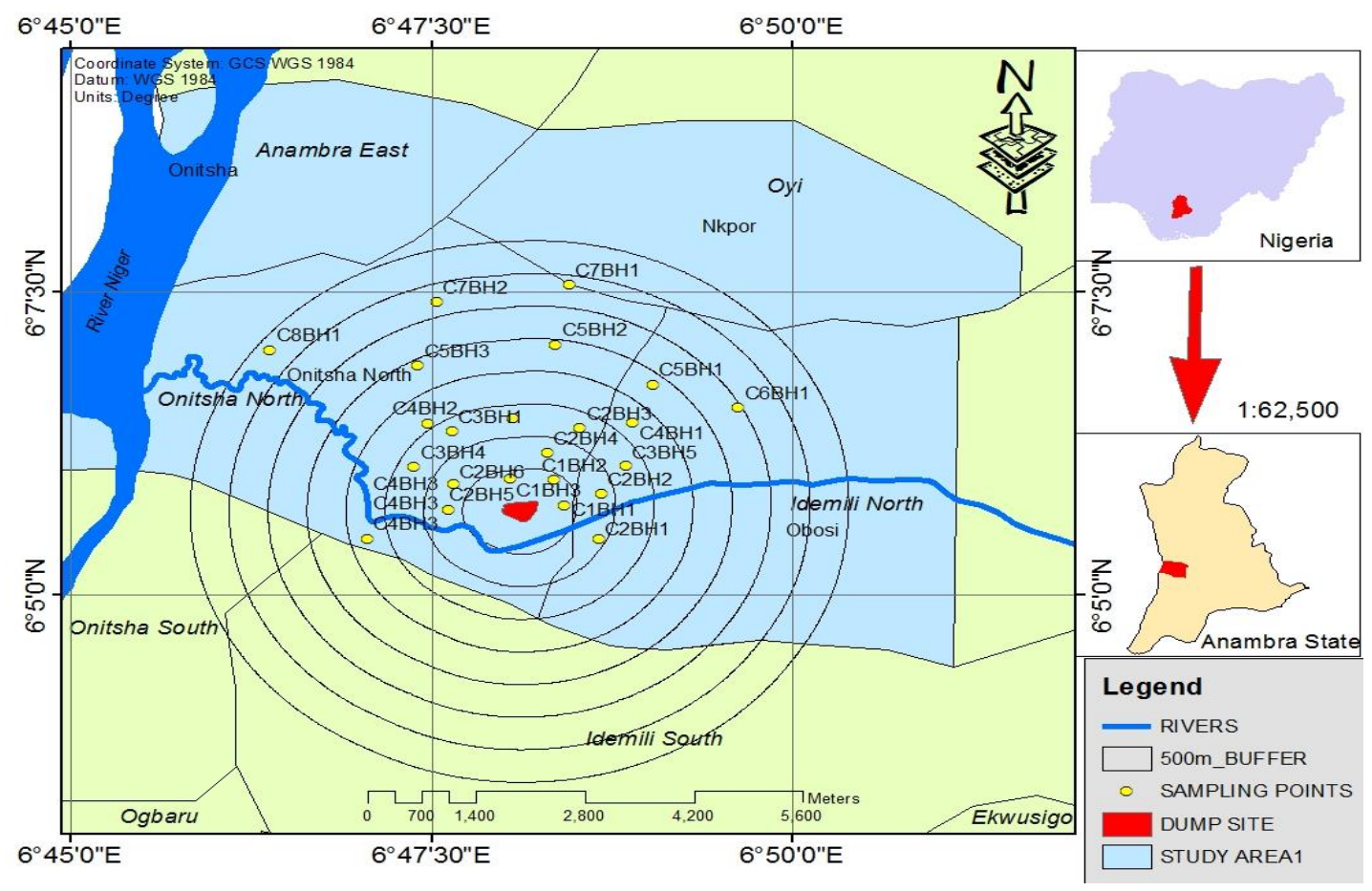

Figure 3.0: Digitized map of the study area showing the sampling points

\subsubsection{Physicochemical analysis:}

In order to observe the variation in quality of water due to landfill leachate, the samples collected from hand pumps in airtight sterilized plastic bottles were subjected to analysis of some physicochemical water quality parameters such as temperature, Electrical conductivity(EC), $\mathrm{pH}$, Total dissolved solids(TDS), Dissolved Oxygen(DO), free Carbondioxide, Alkalinity, Chloride, Total hardness, Calcium hardness, Magnesium content and Biological Oxygen Demand(BOD)as per the methods of assessment of groundwater quality described in "Standard Methods for the examination of Water and Waste water, American Public Health Association [3]. The pH, EC, 
TDS and Temperature were recorded on site with digital $\mathrm{pH}$ meter, digital EC meter, digital TDS meter and digital thermometer respectively. For the analysis of biological oxygen demand(BOD), $250 \mathrm{ml}$ capacity BOD bottles were used for the collection of samples and dissolved oxygen was fixed on site. The dissolved oxygen and BOD was estimated by Azide modification of Wrinkler method[3]. The free CO2, Alkalinity, Chloride, Total hardness, Calcium hardness and Magnesium content were analyzed by titrimetric method[3].

\subsubsection{Bacteriological Parameters:}

For the bacteriological examination, the water samples were collected in airtight sterilized glass bottles and immediately sent to the laboratory for analysis. These samples were then kept in refrigerator at temperature below 40C until analyzed. Total coliform, Fecal coliform and Fecal streptococci organisms were studied by using the standard multiple tube dilution tests for the estimation of number of coliform and Streptococcus groups[3, 1$]$.

\section{RESULTS AND DISCUSSION}

A total of 8 study cells comprising of 24 bore hole water samples used by people residing in close vicinity of Obosi waste dump site were analyzed and the results of mean concentrations of measured parameters in each study cell is displayed in Table 1. The obtained results were compared with the WHO, NESREA, EU and NIS Drinking Water Standards as shown in Table 2. The data revealed that there were considerable variations in the examined samples from different sources with respect to their physicochemical and bacteriological characteristics.

Table 1: Mean levels of measured parameters in the study cells.

\begin{tabular}{|c|c|c|c|c|c|c|c|c|c|c|c|c|}
\hline \multirow[t]{2}{*}{ Parameter } & \multicolumn{8}{|c|}{ Mean concentrations in Study cells } & \multicolumn{4}{|c|}{ LEACHATES } \\
\hline & $\mathrm{C} 1$ & $\mathrm{C} 2$ & C3 & $\mathrm{C} 4$ & $\mathrm{C} 5$ & C6 & C7 & $\mathrm{C} 8$ & L1 & L2 & L3 & L4 \\
\hline Colour (PCU) & 17 & 7 & 30 & 34 & 20 & 12 & 22 & 8 & 3800 & 4180 & 2400 & 2090 \\
\hline $\begin{array}{l}\text { Turbidity } \\
\text { (NTU) }\end{array}$ & 2.46 & 5.12 & 6.08 & 6.33 & 5.95 & 4.77 & 6.54 & 4.88 & 1194 & 1149 & 1581 & 920 \\
\hline $\begin{array}{l}\text { Alkalinity(As } \\
\left.\mathrm{CaCO}_{3}\right) \mathrm{mg} / \mathrm{L}\end{array}$ & 25.00 & 22.96 & 30.00 & 31.12 & 51.67 & 65.00 & 9.15 & 8.19 & 2550 & 2500 & 1350 & 2650 \\
\hline $\mathrm{pH}$ & 5.2 & 5.36 & 5.55 & 5.73 & 6.10 & 5.00 & 5.73 & 5.52 & 6.1 & 5.9 & 6.3 & 7.2 \\
\hline TDS (mg/L) & 120.68 & 143.17 & 108.03 & 49.54 & 100.10 & 300.30 & 17.42 & 54.21 & 5850 & 5655 & 2795 & 3900 \\
\hline $\mathrm{DO}(\mathrm{mg} / \mathrm{L})$ & 11.50 & 11.42 & 12.78 & 10.54 & 12.30 & 11.90 & 4.44 & 5.96 & 8.6 & 9.2 & 8.6 & 9.6 \\
\hline $\mathrm{BOD}(\mathrm{mg} / \mathrm{L})$ & 5.00 & 5.37 & 5.93 & 5.10 & 6.10 & 5.00 & 2.14 & 2.00 & 4.5 & 5.8 & 5.1 & 6.3 \\
\hline Temp. ${ }^{\circ} \mathrm{C}$ & 21.27 & 23.75 & 24.53 & 24.17 & 23.27 & 21.00 & 24.95 & 24.20 & 27.4 & 27.3 & 25.4 & 25.6 \\
\hline $\begin{array}{l}\text { Conductivity } \\
\mu \mathrm{S} / \mathrm{cm}\end{array}$ & 185.67 & 216.27 & 164.50 & 61.33 & 154.00 & 462.00 & 19.45 & 53.30 & 9000 & 8700 & 4300 & 6000 \\
\hline
\end{tabular}




\begin{tabular}{|c|c|c|c|c|c|c|c|c|c|c|c|c|}
\hline $\mathrm{Cl}^{-}(\mathrm{mg} / \mathrm{L})$ & 0.26 & 0.19 & 0.18 & 0.15 & 0.20 & 0.19 & 0.19 & 0.18 & & & & \\
\hline $\mathrm{SO}_{4}{ }^{2-}(\mathrm{mg} / \mathrm{L})$ & 8.33 & 8.94 & 0.00 & 28.00 & 0.00 & 0.00 & 27.74 & 25.19 & 30 & 35 & 25 & 20 \\
\hline $\mathrm{NO}_{3}{ }^{-}(\mathrm{mg} / \mathrm{L})$ & 18.93 & 227.22 & 300.70 & 219.62 & 281.97 & 232.60 & 47.35 & 78.01 & 164 & 318 & 644 & 23 \\
\hline $\mathrm{Ca}^{2+}(\mathrm{mg} / \mathrm{L})$ & 1.15 & 4.99 & 0.71 & 4.26 & 0.43 & 2.04 & 4.20 & 6.43 & 33.87 & 32.46 & 35.98 & 33.53 \\
\hline $\mathrm{Mg}^{2+}(\mathrm{mg} / \mathrm{L})$ & 1.33 & 2.96 & 2.35 & 1.89 & 1.78 & 0.52 & 0.27 & 0.14 & 21.81 & 20.35 & 20.46 & 21.23 \\
\hline $\mathrm{K}^{+}(\mathrm{mg} / \mathrm{L})$ & 3.51 & 9.76 & 5.65 & 4.59 & 2.57 & 0.00 & 2.02 & 7.38 & 11.27 & 12.36 & 11.39 & 10.38 \\
\hline $\mathrm{Na}^{+}(\mathrm{mg} / \mathrm{L})$ & 1.47 & 3.01 & 3.87 & 9.05 & 3.85 & 4.63 & 5.50 & 14.21 & 4.15 & 4.27 & 5.63 & 5.83 \\
\hline $\operatorname{As}(\mathrm{mg} / \mathrm{L})$ & BDL & 0.013 & 0.013 & 0.018 & BDL & 0.017 & BDL & BDL & 2.36 & BDL & BDL & BDL \\
\hline $\mathrm{Pb}(\mathrm{mg} / \mathrm{L})$ & 0.213 & 0.454 & 0.374 & 0.640 & 0.563 & 0.981 & 0.364 & 0.888 & 0.41 & 0.33 & 0.51 & 0.38 \\
\hline $\mathrm{Cu}(\mathrm{mg} / \mathrm{L})$ & 0.016 & 0.097 & 0.013 & 0.177 & 0.022 & 0.022 & 0.775 & 0.981 & 0.203 & 0.169 & 0.289 & 0.268 \\
\hline $\mathrm{Mn}(\mathrm{mg} / \mathrm{L})$ & 0.210 & 0.648 & 0.514 & 0.573 & 0.580 & 0.792 & 0.220 & 0.207 & 9.668 & 9.448 & 4.326 & 2.177 \\
\hline $\mathrm{Fe}(\mathrm{mg} / \mathrm{L})$ & 0.377 & 0.393 & 0.008 & 0.429 & 0.246 & 0.021 & 2.105 & 2.905 & 44.63 & 42.64 & 26.55 & 15.54 \\
\hline $\mathrm{Hg}(\mathrm{mg} / \mathrm{L})$ & 0.755 & 0.424 & 0.609 & 1.042 & 0.707 & 0.738 & 1.450 & 0.111 & 1.4 & 1.0 & 0.9 & 1.1 \\
\hline Total Coliform & 29 & 19 & 24 & 26 & 23 & 18 & 6 & 3 & $1.2 \times 10^{5}$ & $1.6 \times 10^{5}$ & $4.9 \times 10^{5}$ & $1.7 \times 10^{5}$ \\
\hline $\begin{array}{l}\text { Faecal } \\
\text { Coliform }\end{array}$ & $<3$ & $<3$ & $<3$ & $<3$ & $<3$ & $<3$ & $<3$ & $<3$ & $1.5 \times 10^{5}$ & $6.4 \times 10^{4}$ & $1.8 \times 10^{5}$ & $2.2 \times 10^{5}$ \\
\hline $\begin{array}{l}\text { Faecal } \\
\text { Streptococci }\end{array}$ & 8 & 5 & 14 & 3 & $<3$ & $<3$ & $<3$ & $<3$ & - & - & - & - \\
\hline
\end{tabular}

Note: The range and mean values of microbial counts were in $\mathrm{cfu} / 100 \mathrm{ml}$ of water.

\subsubsection{Physicochemical Characteristics of Ground water Samples:}

The descriptive statistics of the physicochemical parameters shown in Table 2, revealed that the levels of Electrical conductivity $(\mathrm{EC})($ Range $=692.00 \mu \mathrm{S} / \mathrm{cm})$, Total Dissolved Solids (TDS) $($ Range $=441.45 \mathrm{mg} / \mathrm{l})$, Salinity $($ Range $=894.00 \%)$, Alkalinity $($ Range $=123.81 \mathrm{mg} / \mathrm{l}$ as CaCO3), HCO3-ion (Range $=1282.00 \mathrm{mg} / \mathrm{l})$, SO42- ion $($ Range $=800.00 \mathrm{mg} / \mathrm{l}), \mathrm{Cl}$ - ion $($ Range $=390.03 \mathrm{mg} / \mathrm{l}), \mathrm{CO} 32-($ Range $=119.95 \mathrm{mg} / \mathrm{l})$ and NO3- $($ Range $=357.70 \mathrm{mg} / \mathrm{l})$ varied widely while the other parameters had narrow variations. These observed wide variations indicate significant source input above the regulatory levels of the parameters. The source input was definitely the waste dump site and other anthropogenic activities going on proximal to the aquifer and groundwater studied. The source contributors of Electrical Conductivity (EC), total dissolved solids, Salinity and such ions as $\mathrm{Cl}-$, SO42-, and NO3- could include such waste components as agricultural and domestic wastes.

Table 2: Descriptive Statistics of Physicochemical Parameters in groundwater around the Obosi waste dumpsite. 
International Journal of Agriculture, Environment and Bioresearch

Vol. 4, No. 04; 2019

ISSN: 2456-8643

\begin{tabular}{|c|c|c|c|c|c|c|c|c|c|}
\hline \multirow[t]{2}{*}{ Parameters } & \multicolumn{5}{|c|}{ Concentrations } & \multicolumn{4}{|c|}{ Regulatory Standards } \\
\hline & Minimum & Maximum & Range & Mean & $\begin{array}{l}\text { Standard } \\
\text { Error }\end{array}$ & $\begin{array}{l}\text { WHO } \\
\text { (2011) }\end{array}$ & $\begin{array}{l}\text { NESREA } \\
\text { (2011) }\end{array}$ & $\begin{array}{l}\text { EU } \\
(1998)\end{array}$ & $\begin{array}{l}\text { NIS } \\
\text { (2007) }\end{array}$ \\
\hline $\mathrm{pH}$ & 5.00 & 6.80 & 1.80 & 5.7309 & 0.07242 & $6.5-8.5$ & $6.5-9.2$ & & $6.5-8.5$ \\
\hline Temperature $\left({ }^{\circ} \mathrm{c}\right)$ & 23.80 & 34.80 & 11.00 & 29.3478 & 0.38102 & & & & \\
\hline $\mathrm{EC}(\mu \mathrm{s} / \mathrm{cm})$ & 23.00 & 695.00 & 692.00 & 163.4065 & 2.98908 & 250 & & 250 & 1000 \\
\hline TDS (Mg/L) & 97.70 & 451.15 & 441.45 & 104.5257 & 2.19882 & 500 & & & 500 \\
\hline Turbidity (Ntu) & 0.00 & 55.00 & 55.00 & 10.0213 & 1.72644 & $<5$ & & & $<5$ \\
\hline Colour & 0.00 & 197.00 & 197.00 & 27.5870 & 5.43451 & & 50 units & & $15 \mathrm{TCU}$ \\
\hline $\mathrm{DO}(\mathrm{Mg} / \mathrm{L})$ & 3.50 & 14.40 & 10.90 & 7.9285 & 0.56869 & $150-500$ & 5 & 5 & 5 \\
\hline $\mathrm{BOD}(\mathrm{Mg} / \mathrm{L})$ & 0.10 & 7.90 & 7.80 & 3.1948 & 0.34565 & & & & \\
\hline Salinity $(\mathrm{Mg} / \mathrm{L})$ & 109.00 & 903.00 & 894.00 & 296.3913 & 2.18817 & & & & \\
\hline Alkalinity $(\mathrm{Mg} / \mathrm{L})$ & .00 & 123.81 & 123.81 & 45.4689 & 4.68800 & $5-500$ & & & 100 \\
\hline $\mathrm{Ca}^{2+}$ & .00 & 7.83 & 7.83 & 1.4260 & 0.33419 & 75 & & & \\
\hline $\mathrm{Mg}^{2+}$ & .00 & 7.01 & 7.01 & .9924 & 0.27438 & $20-125$ & & $20-125$ & 0.2 \\
\hline $\mathrm{Na}^{+}$ & .00 & 25.89 & 25.89 & 6.3278 & 0.94828 & 200 & & 200 & 200 \\
\hline $\mathrm{K}^{+}$ & .00 & 20.00 & 20.00 & 3.0108 & 0.62964 & & & & \\
\hline $\mathrm{HCO}_{3}^{-}$ & 1100.00 & 1300.00 & 1282.00 & 371.6087 & 1.47526 & & & & \\
\hline $\mathrm{SO}_{4}{ }^{2-}$ & 700.00 & 800.00 & 800.00 & 281.6800 & 3.51066 & 500 & 400 & 250 & 100 \\
\hline $\mathrm{Cl}^{-}$ & 270 & 390.10 & 390.03 & 67.1946 & 1.01726 & 250 & 600 & 250 & 250 \\
\hline $\mathrm{CO}_{3}^{-}$ & .05 & 120.00 & 119.95 & 35.3530 & 5.82113 & & & & \\
\hline $\mathrm{NO}_{3}^{-}$ & 3.90 & 361.60 & 357.70 & 145.9498 & 17.30100 & 50 & 50 & 50 & 50 \\
\hline As & .00 & .14 & .14 & .0087 & 0.00417 & 0.01 & & 0.01 & 0.01 \\
\hline $\mathrm{Pb}$ & .02 & 1.62 & 1.60 & .4810 & 0.05835 & 0.01 & & 0.01 & 0.01 \\
\hline $\mathrm{Cu}$ & .00 & 1.92 & 1.92 & .1666 & 0.05528 & 2.0 & 1.5 & 2.0 & 1.0 \\
\hline $\mathrm{Cr}$ & .00 & 4.40 & 4.40 & .6123 & 0.16861 & 0.05 & & 0.05 & 0.05 \\
\hline Co & .00 & 3.15 & 3.15 & .3331 & 0.11622 & & & & \\
\hline $\mathrm{Ni}$ & .00 & .20 & .20 & .0342 & 0.00835 & 0.02 & & 0.02 & 0.02 \\
\hline
\end{tabular}


International Journal of Agriculture, Environment and Bioresearch

Vol. 4, No. 04; 2019

ISSN: $2456-8643$

\begin{tabular}{|lcccccccccc} 
& .00 & 3.15 & 3.15 & .4986 & 0.09364 & 0.5 & 0.5 & 0.05 & 0.2 \\
$\mathrm{Fe}$ & .00 & 5.81 & 5.81 & .5512 & 0.16806 & 0.3 & 1.0 & 0.2 & 0.3 \\
$\mathrm{Cd}$ & .00 & .38 & .38 & .0613 & 0.01122 & 0.003 & & 0.005 & 0.003 \\
$\mathrm{Hg}$ & .00 & 2.80 & 2.80 & .7061 & 0.11360 & 0.001 & & 0.001 & 0.001 \\
\hline
\end{tabular}

The total dissolved solid (TDS) is a valuable indicator of the total dissolved salt content of water. The very high EC and TDS observed in the groundwater suggest a downward transfer of leachate into groundwater [20,2,17]. High concentrations of TDS decrease the palatability of water and may also cause gastro-intestinal irritation in humans and laxative effects particularly upon transits [30].

However, the salinity hazard rating for the water samples using Electrical Conductivity (EC)[29], revealed that the groundwater in both seasons ranged between good to excellent. Also according to saline water classification using TDS [8], all the water samples are fresh. In the same vein, the Salinity classification of groundwater samples[24], indicated that all the groundwater samples are fresh with salinity values less than $1000 \mathrm{mg} / \mathrm{l}$.

Alkalinity, $\mathrm{CO} 32-$ and HCO3- sources could be traced to the leaching of rock minerals such as limestone and dolomite which are commonly found and mined in the area. High concentrations of sulphate may interfere in the efficiency of chlorination in some public water supplies. Also, sulphate salts may increase the corrosive properties of water. The United States Environmental Protection Agency (USEPA) has set a maximum contaminant level of $250 \mathrm{mg} / \mathrm{l}$ for sulphate in public water supplies [28].High Cl- content of groundwater is likely to originate from waste sources including domestic effluents, fertilizers, septic tanks and from natural sources such as rainfall and the dissolution of fluid inclusions. Increases in Cl- level could be injurious to people suffering from diseases of heart or kidney [7].

Due to its high mobility, nitrate leaches into groundwater unhindered [25]. If people or animals drink water high in nitrate, it may cause methemoglobinemia, an illness found especially in infants [25].

$\mathrm{pH}$, water temperature and electrical conductivity varied from 5.00-6.80 (5.73 \pm 0.07$), 23.80$ $34.80(29.35 \pm 0.38){ }^{\circ} \mathrm{C}$ and $23.00-695.00(163.41 \pm 2.99) \mu \mathrm{S} / \mathrm{cm}$ respectively. TDS varied from $97.70-451.15(9.70 \pm 2.20) \mathrm{mg} / \mathrm{L}$, Turbidity from $0.00-55.00(10.02 \pm 1.73)$ NTU and Colour from $0.00-197.00(27.59 \pm 5.44)$ PCU. The variations for DO, BOD, Salinity and Alkalinity were $3.50-14.40(7.93 \pm 0.57) \mathrm{mg} / \mathrm{L}, 0.1-7.90(3.20 \pm 0.35) \mathrm{mg} / \mathrm{L}, 9.00-903.00(296.39 \pm 2.19)$ $\mathrm{mg} / \mathrm{L}$ and $0.00-123.81(45.47 \pm 4.69) \mathrm{mg} / \mathrm{L}$ as $\mathrm{CaCO} 3$ respectively. These are represented in Table 2 .

$\mathrm{Ca}+$ ions varied from $0.00-7.83(1.43 \pm 0.33) \mathrm{mg} / \mathrm{L}, \mathrm{Mg}+$ ions varied from $0.00-7.01$ $(0.99 \pm 0.27) \mathrm{mg} / \mathrm{L}, \mathrm{Na}+$ ions varied from $0.00-25.89(6.33 \pm 0.95) \mathrm{mg} / \mathrm{L}$ and $\mathrm{K}+$ ion varied from $0.00-20.00(3.01 \pm 0.63) \mathrm{mg} / \mathrm{L}$. HCO3-ion varied from $1100.00-1300.00(371.61 \pm 1.48) \mathrm{mg} / \mathrm{L}$, 
SO4- ion varied from $700.00-800.00(218.68 \pm 3.51) \mathrm{mg} / \mathrm{L}$ and $\mathrm{Cl}$-ion varied from $270-390.10$ $(67.20 \pm 1.02) \mathrm{mg} / \mathrm{L}$. The result also revealed that CO32- ion and NO3- ion varied from $0.05-$ $120.00(35.35 \pm 5.82) \mathrm{mg} / \mathrm{L}$ and $3.90-361.60(145.95 \pm 17.30) \mathrm{mg} / \mathrm{L}$ respectively as shown in Table 2.

$\mathrm{As}, \mathrm{Pb}, \mathrm{Cu}, \mathrm{Cr}, \mathrm{Co}, \mathrm{Ni}, \mathrm{Mn}, \mathrm{Fe}, \mathrm{Cd}$ and $\mathrm{Hg}$ varied from $0.00-0.14(0.01 \pm 0.004) \mathrm{mg} / \mathrm{L}, 0.02-$ $1.62(0.48 \pm 0.06) \mathrm{mg} / \mathrm{L}, 0.00-1.92(0.17 \pm 0.06) \mathrm{mg} / \mathrm{L}, 0.00-4.40(0.61 \pm 0.17) \mathrm{mg} / \mathrm{L}, 0.00-3.15$ $(0.33 \pm 0.12) \mathrm{mg} / \mathrm{L}, 0.00-0.20(0.03 \pm 0.01) \mathrm{mg} / \mathrm{L}, 0.00-3.15(0.50 \pm 0.09) \mathrm{mg} / \mathrm{L}, 0.00-5.81$ $(0.55 \pm 0.17) \mathrm{mg} / \mathrm{L}, 0.00-0.38(0.061 \pm 0.01) \mathrm{mg} / \mathrm{L}$ and $0.00-2.80(0.71 \pm 0.11) \mathrm{mg} / \mathrm{L}$ respectively (Table 2).

The acidic nature of Obosi groundwater is characteristic of alluvial groundwater whose $\mathrm{pH}$ is primarily controlled by its hydrogeological setting [17]. Accordingly, the observation of the most acidic water from the boreholes closest to the waste dump site is an indication that the impact of leachate cannot be ruled out. One major implication of this is the corrosion of plumbing materials [13].

The presence of high levels of some heavy metals such as $\mathrm{As}, \mathrm{Pb}, \mathrm{Cu}, \mathrm{Cr}, \mathrm{Mn}, \mathrm{Fe}$ and $\mathrm{Hg}$ in some of the groundwater suggests their origin could be from the various wastes dumped in the landfill and from other anthropogenic activities in the area.

Although, arsenic is a natural element, it is also one of the components of a large number of compounds generated by human activities such as electronics wastes, precious metals mining, pharmaceutical manufacturing, wood processing, glassmaking, chemical weapons etc. Arsenic is also widely used in agriculture as a fungicide. The presence of this contaminant in some of the borehole samples could be traced to such sources as mentioned above. Chronic exposure to drinking water with a high As content is known to lead to the development of various forms of cancer affecting the skin, lungs and digestive system [16].

Elevated levels of $\mathrm{Pb}$ may also be attributed largely to the disposal of batteries, lead-based paints and lead pipes found at the site. According to [31], lead symptoms range from gastrointestinal disturbances to inflammation of the brain and spinal cord. Brain damage is common among children exposed to high levels of lead. It is known that $\mathrm{Cu}$ is sometimes contributed by contamination from mining operations, acid waters and corrosion in copper plumbing [5]. Cupper poisoning symptoms include jaundice and anemia [13].High levels recorded in this work therefore could predispose consumers of the water to ill health conditions. Results also showed considerable contamination of the water samples with chromium in the study area. Though $\mathrm{Cr}$ may be found naturally in groundwater, it could also be contributed by industrial activities commonly from the plating industry. $\mathrm{Cr}$ can be toxic to humans and produce skin irritations when external exposures occur[4]. Liver and kidney damage may also result from internal exposure.

Manganese is dissolved from shale, sandstone or river basin material and may be found in surface water in swampy areas. Excessive manganese gives water a grayish/black appearance and may stain plumbing fixtures and laundry. Manganese can also produce taste problems. The presence of high concentration of $\mathrm{Fe}$ in the boreholes indicates that Fe scraps are likely dumped 
in the landfill. The proximally located Obosi automobile scrap market is another possible source. Concentration of $\mathrm{Fe}$ above the permissible limit in water results in aesthetic problems relating to taste, odour and colour. Mercury enters the environment mainly through human activities. The chief sources of mercury pollution are chlor-alkali plants, paper, pulp, cellulose and plastic industries, electrical, paint, pharmaceutical industries, etc. Uses of mercury as fungicides, pesticides, etc., also add mercury to the environment. Mercury is also believed to be the most dangerous of all the metal contaminants which may have resulted in numerous poisoning.

Sulfate (SO42-) levels detected in all the sampled cells were all within the NIS, WHO and EU limit value of 100, 500 and $250 \mathrm{mg} / \mathrm{L}$ respectively. However, the Nitrate (NO32-) levels in most of the water samples exceeded the limit value. This shows excessive concentration of nitrates in the samples.

3.0.2 Contour and 3-D Surface Plots of some of the Physicochemical Water Quality Parameters Measured:

The contour and 3-D surface plots of some of the measured physicochemical water quality indices are presented in Figures 4(a) to 18(b). The observed level of each water quality parameter is shown with colours and values of the colours are also clearly indicated with the unit of the water quality index.

$\mathrm{pH}$ :

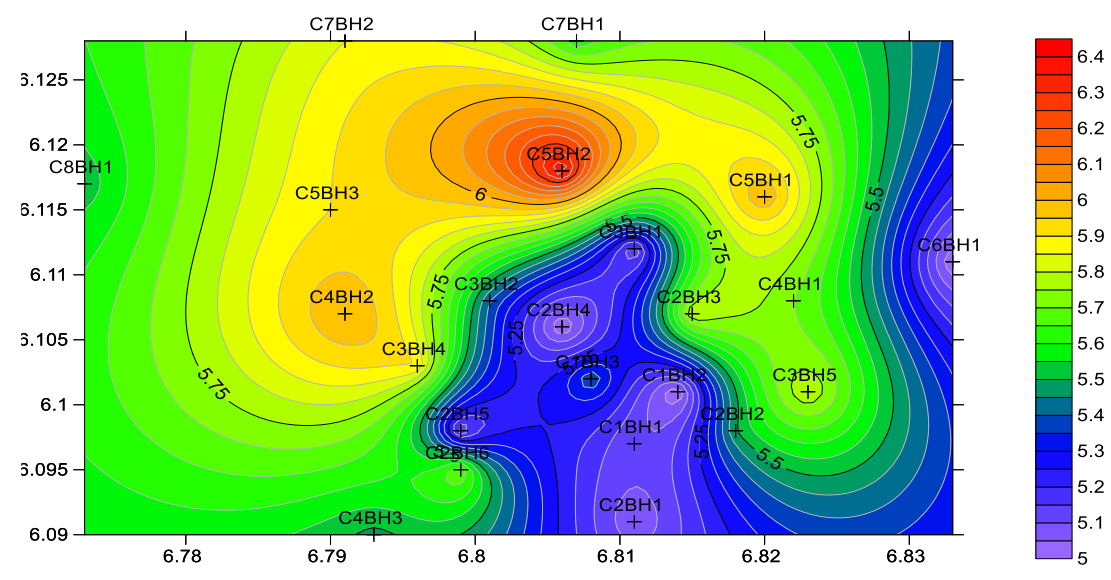

Figure 4(a): Contour map of $\mathrm{pH}$ values in the study area. 

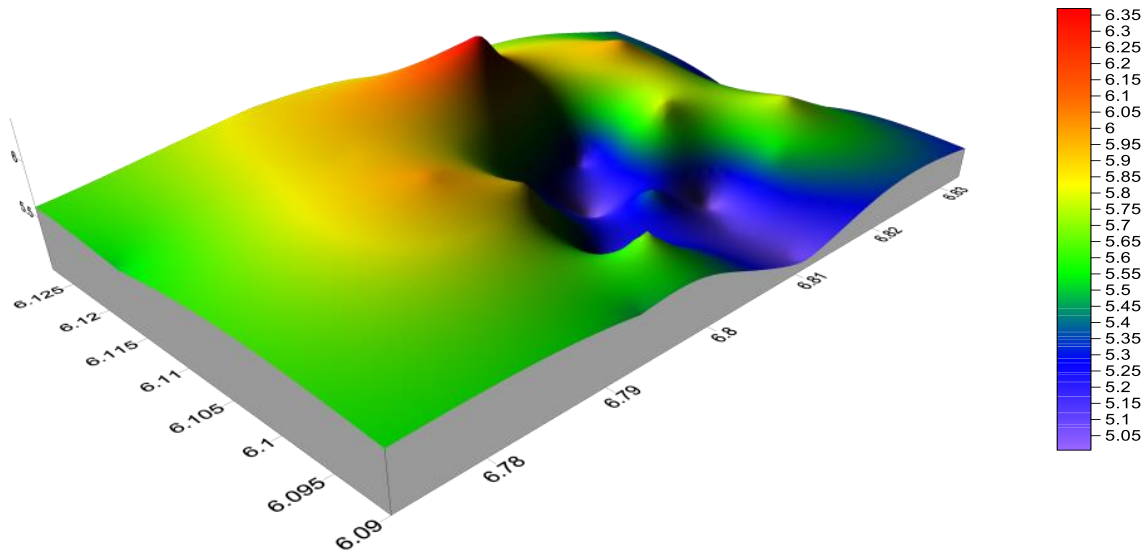

Figure 4 (b): 3-D model of $\mathrm{pH}$ concentrations in the study area.

\section{Electrical Conductivity:}

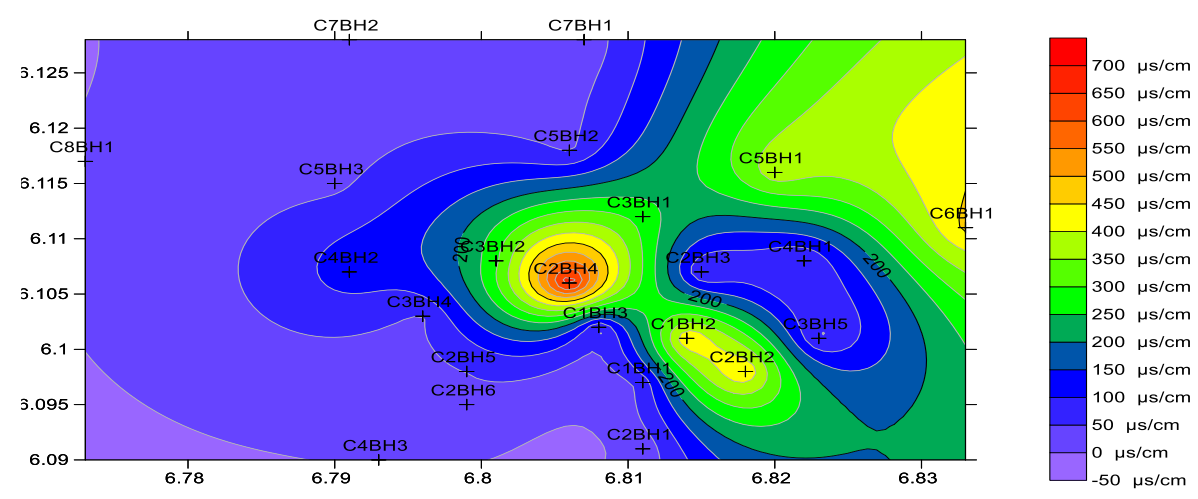

Figure 5 (a):Contour map of Electrical conductivity values in the study area
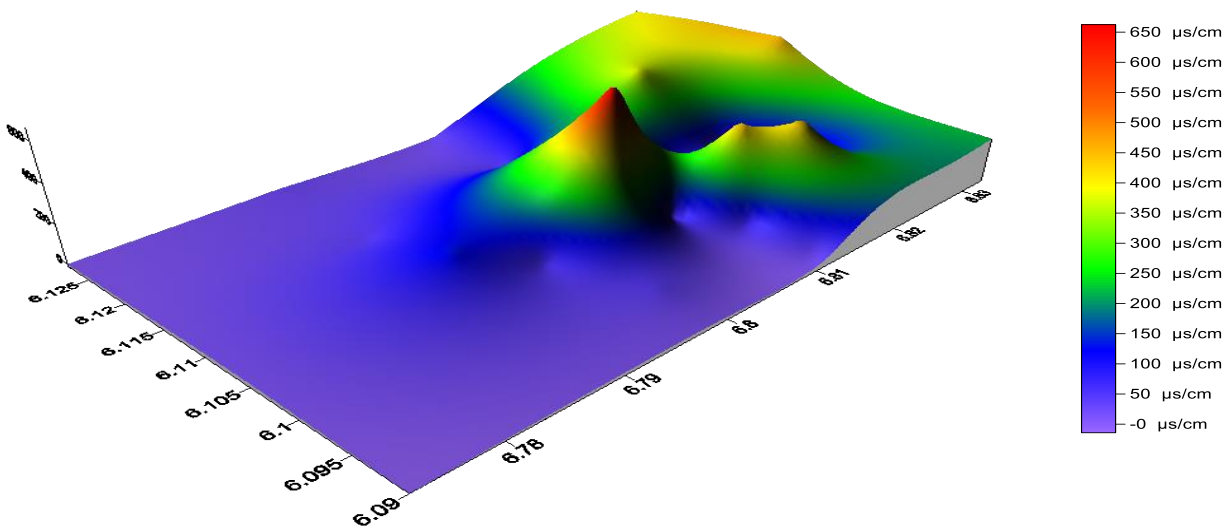

Figure 5 (b):3-D model of Electrical conductivity values in the study area 

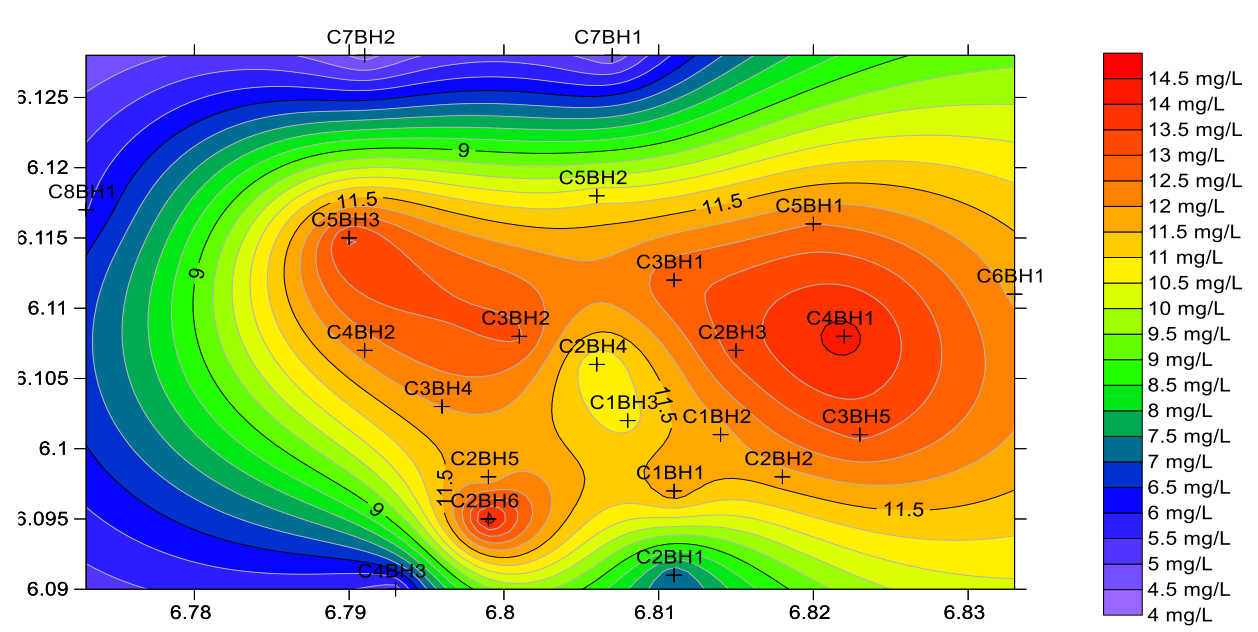

Figure 6 (a):Contour map of DO values in the study area

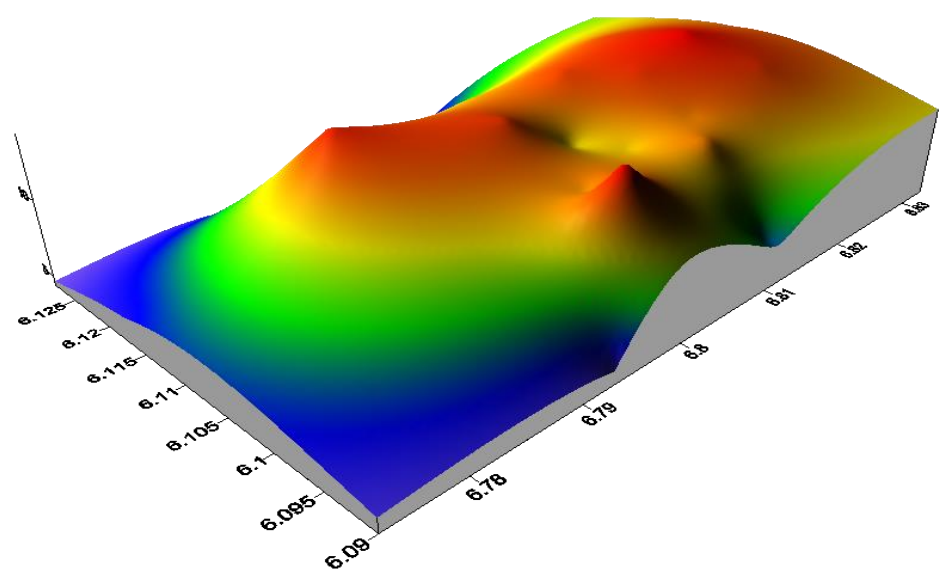

$$
\begin{aligned}
& -14 \mathrm{mg} / \mathrm{L} \\
& -13.5 \mathrm{mg} / \mathrm{L} \\
& 13 \mathrm{mg} / \mathrm{L} \\
& -12.5 \mathrm{mg} / \mathrm{L} \\
& -12 \mathrm{mg} / \mathrm{L} \\
& -11.5 \mathrm{mg} / \mathrm{L} \\
& -11 \mathrm{mg} / \mathrm{L} \\
& -10.5 \mathrm{mg} / \mathrm{L} \\
& -10 \mathrm{mg} / \mathrm{L} \\
& -9.5 \mathrm{mg} / \mathrm{L} \\
& -9 \mathrm{mg} / \mathrm{L} \\
& -8.5 \mathrm{mg} / \mathrm{L} \\
& -8 \mathrm{mg} / \mathrm{L} \\
& -7.5 \mathrm{mg} / \mathrm{L} \\
& -7 \mathrm{mg} / \mathrm{L} \\
& -6.5 \mathrm{mg} / \mathrm{L} \\
& -6 \mathrm{mg} / \mathrm{L} \\
& 5.5 \mathrm{mg} / \mathrm{L} \\
& -5 \mathrm{mg} / \mathrm{L} \\
& -4.5 \mathrm{mg} / \mathrm{L}
\end{aligned}
$$

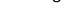

Figure 6 (b):3-D model of DO values in the study area

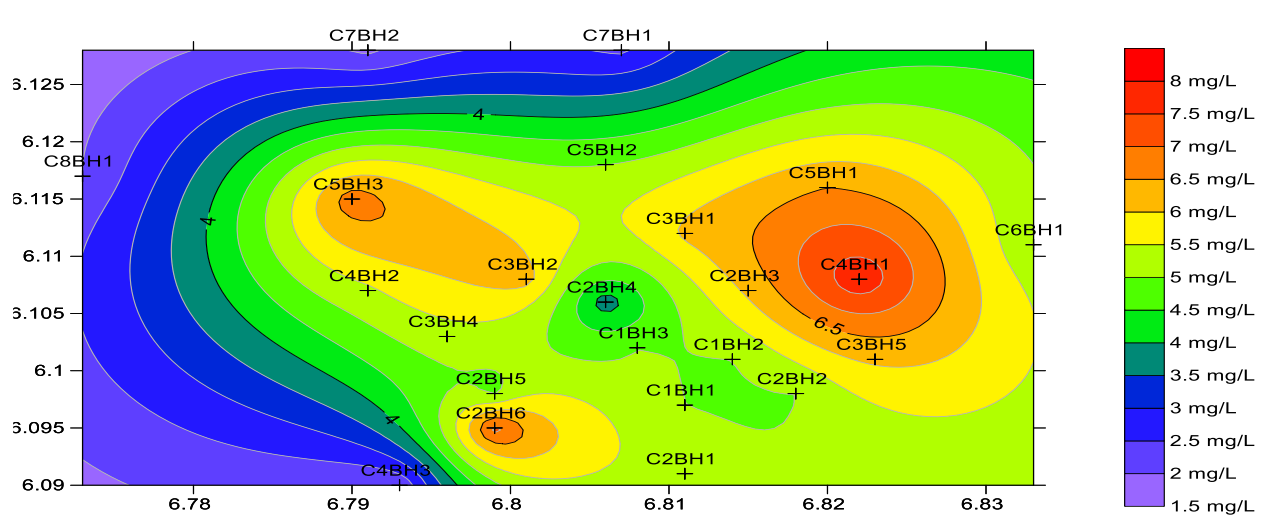

Figure 7 (a):Contour map of BOD values in the study area 


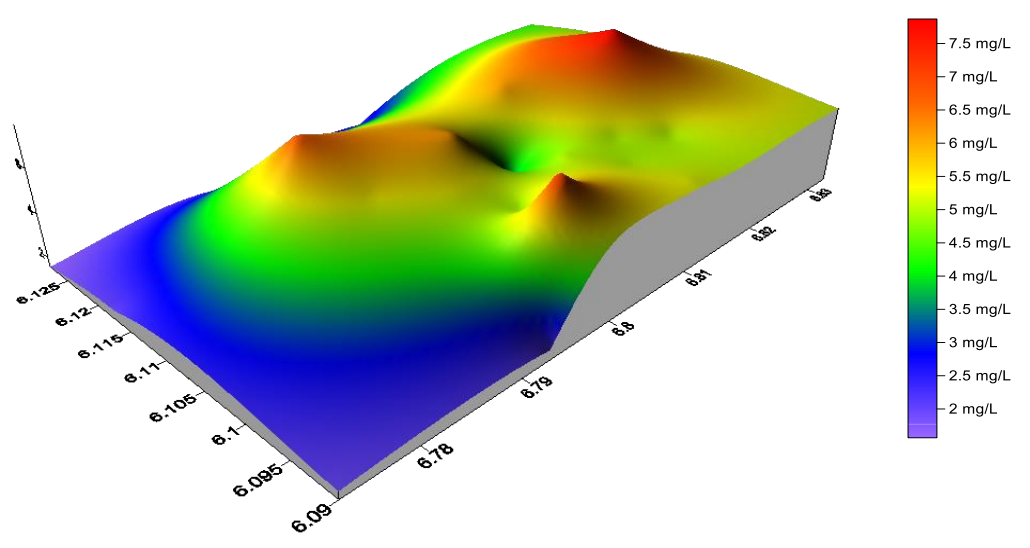

Figure 7 (b):3-D model of BOD values in the study area

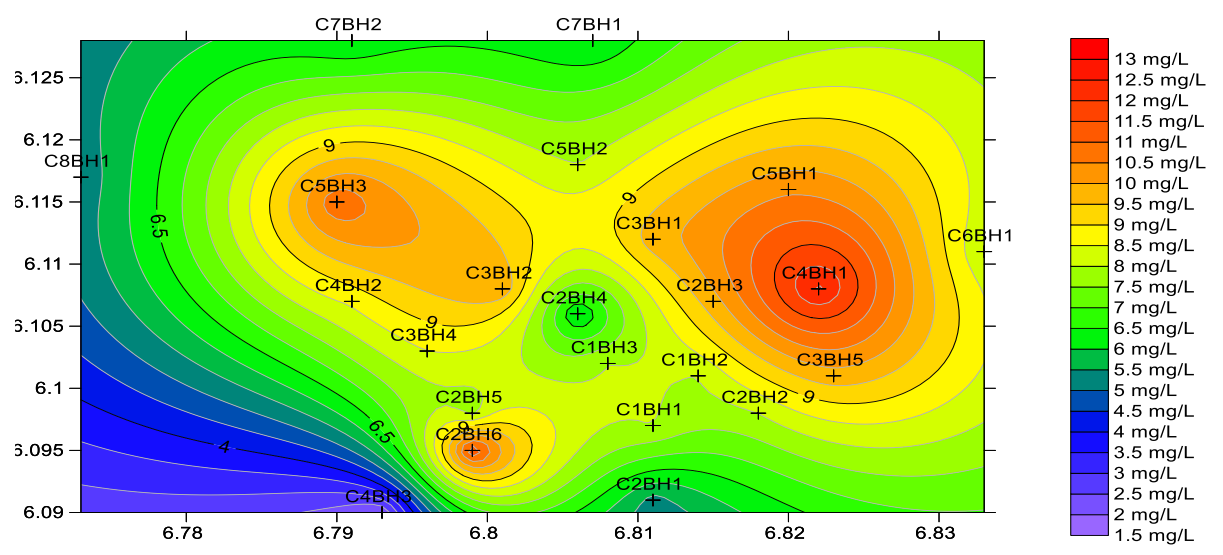

Figure 8 (a): Contour map of COD values in the study area

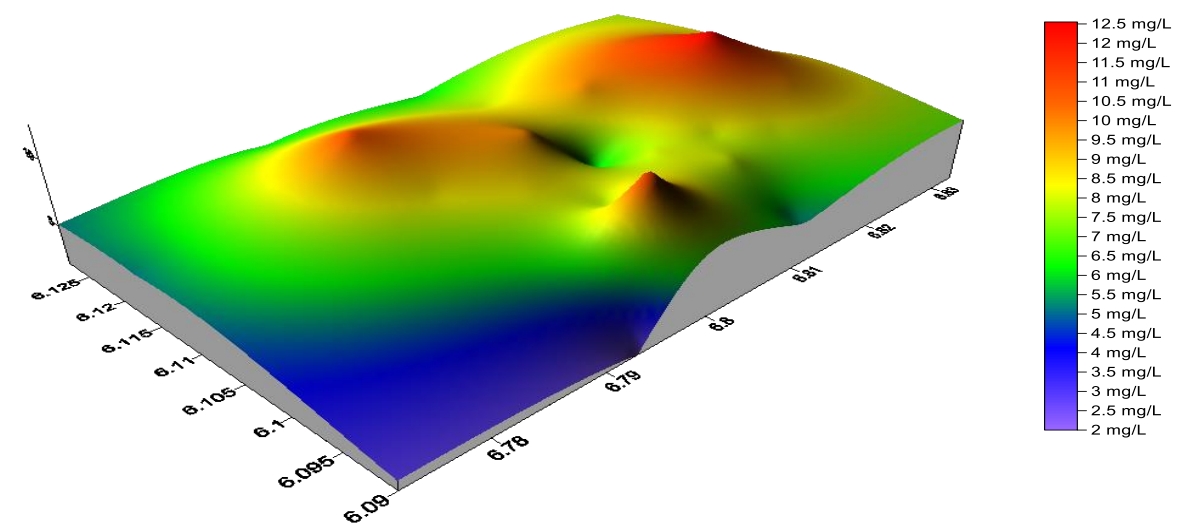

Figure 8 (b): 3-D model of COD values in the study area 


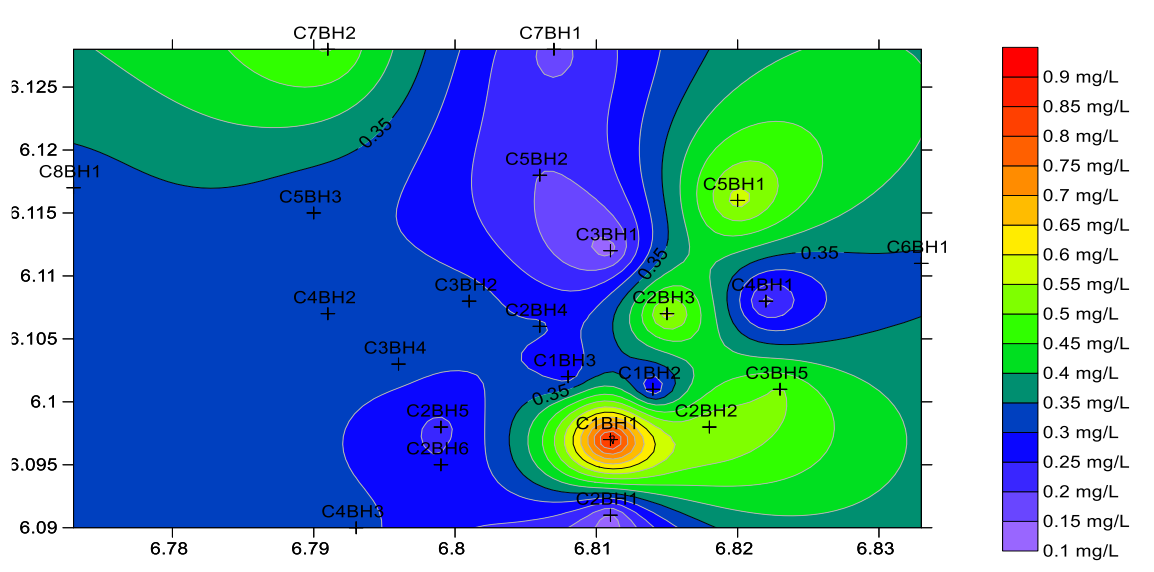

Figure $9(\mathrm{a})$ :Contour map of Salinity values in the study area

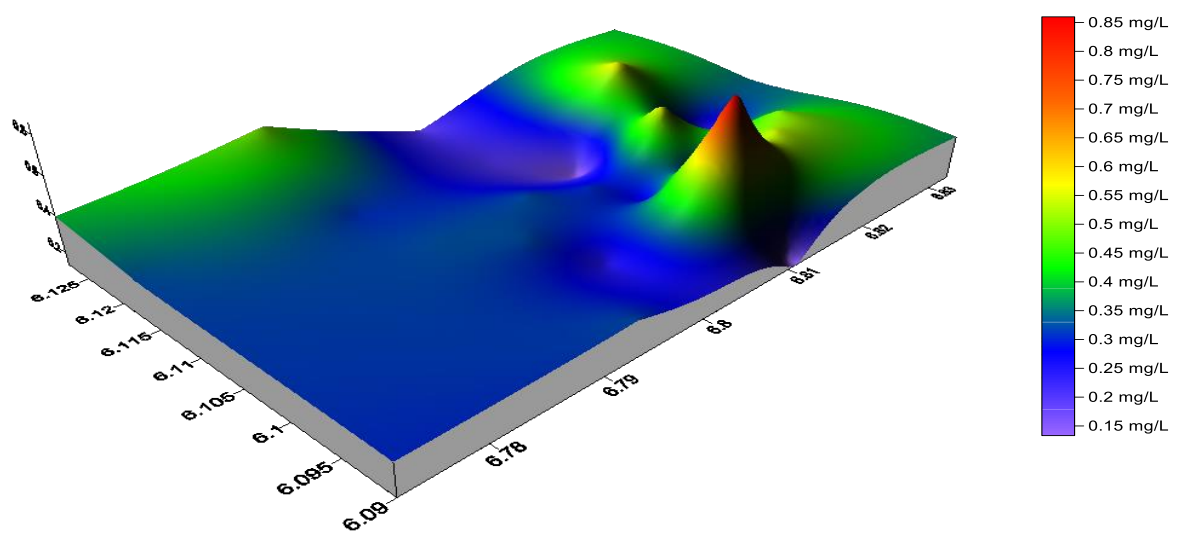

Figure 9 (b):3-D model of Salinity values in the study area

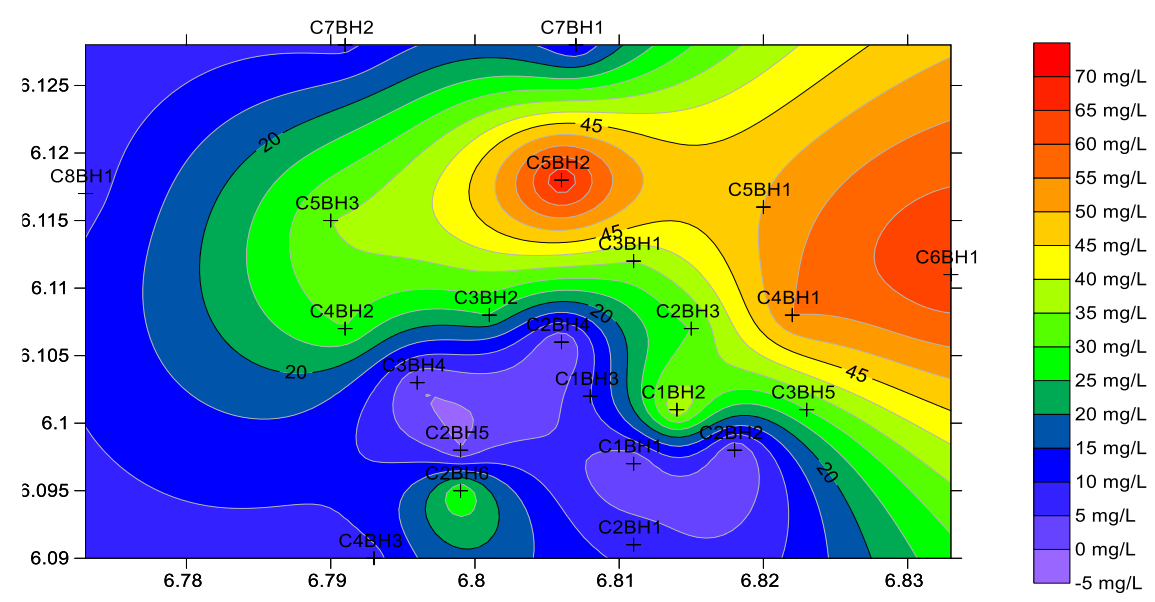

Figure $10(a)$ :Contour map of Alkalinity values in the study area 


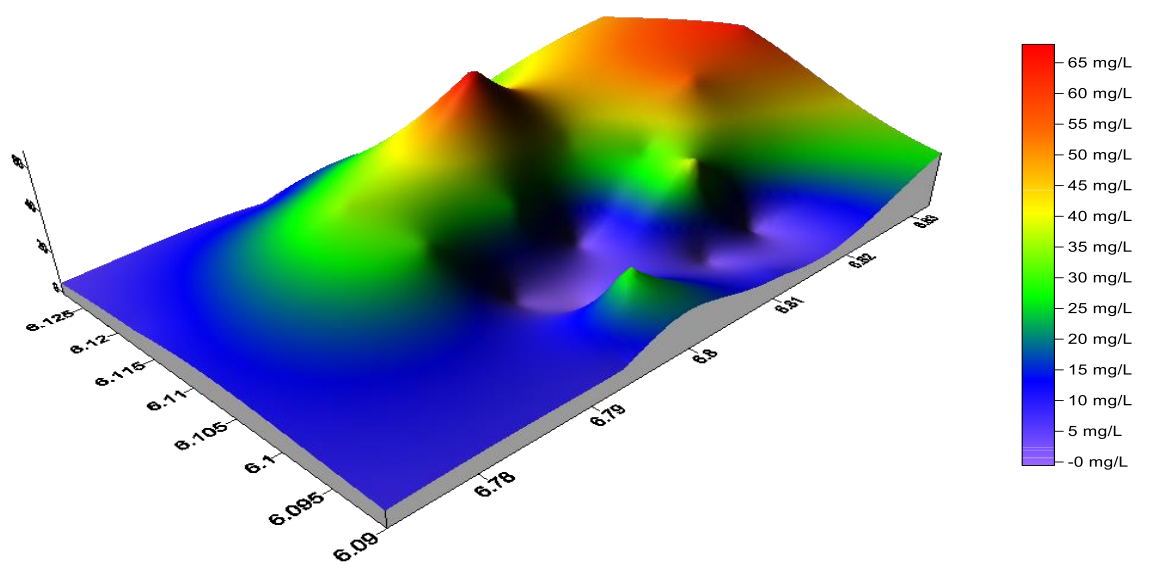

Figure 10 (b):3-D model of Alkalinity values in the study area

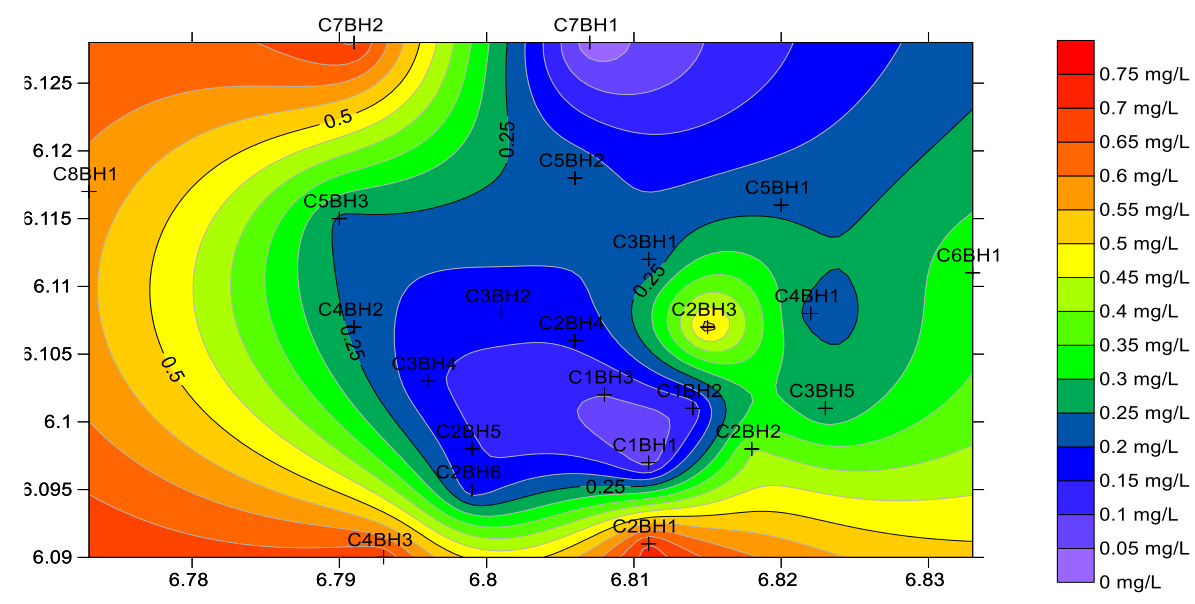

Figure 11 (a):Contour map of Lead values in the study area

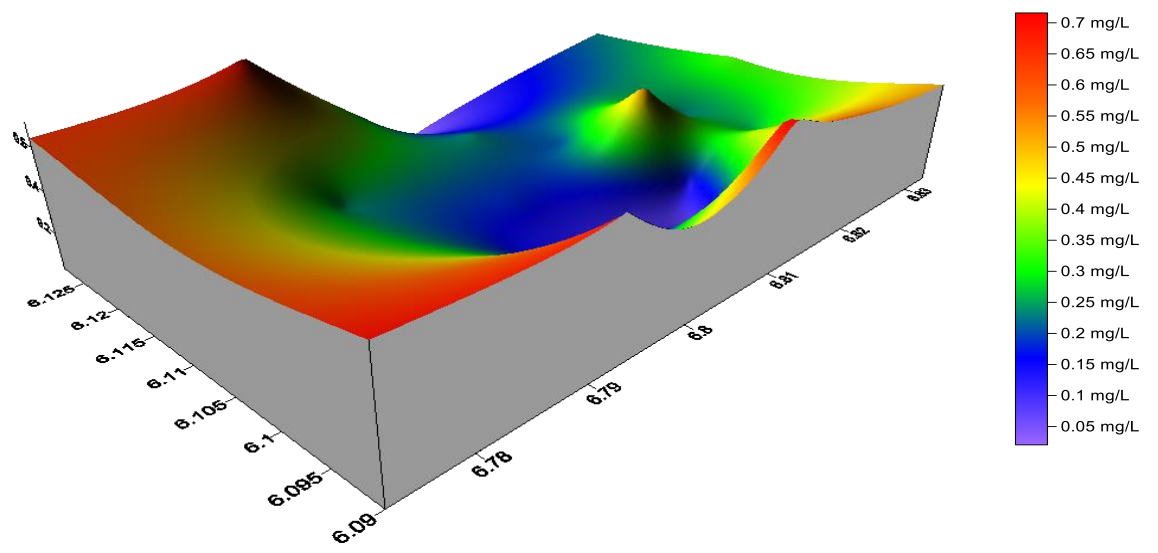

Figure 10 (b):3-D model of Lead values in the study area 


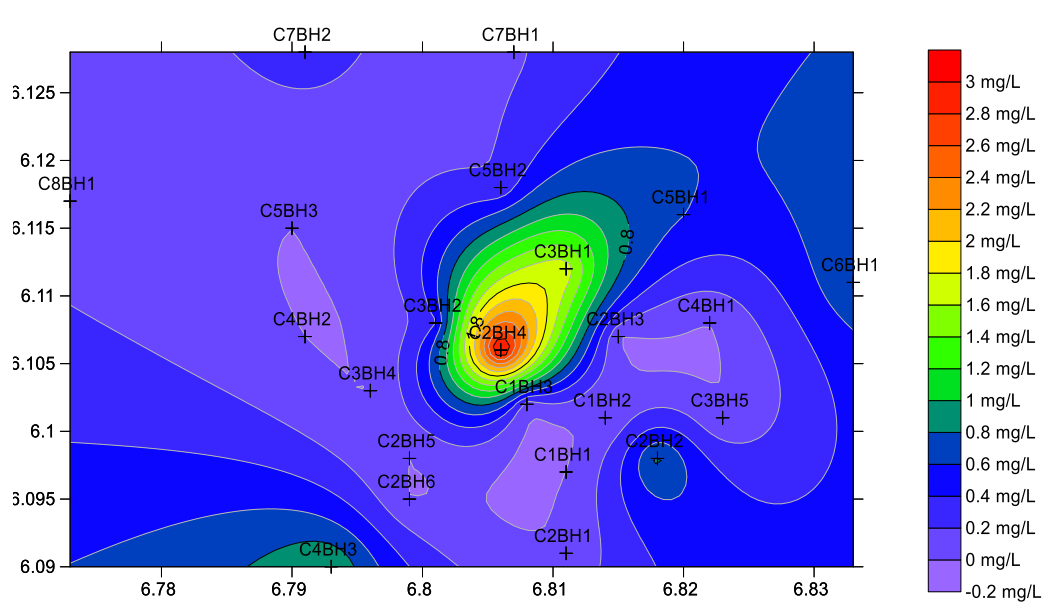

Figure 12 (a):Contour map of Manganese values in the study area

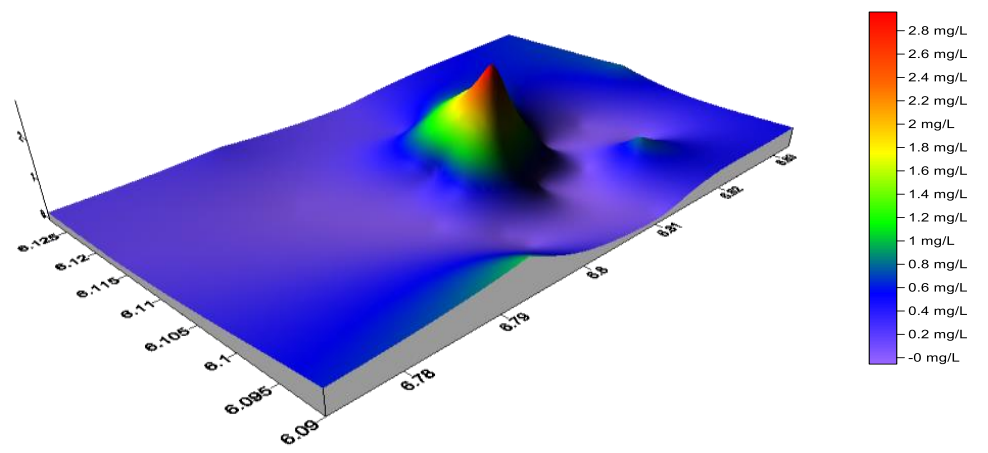

Figure 12 (b):3-D model of Manganese values in the study area

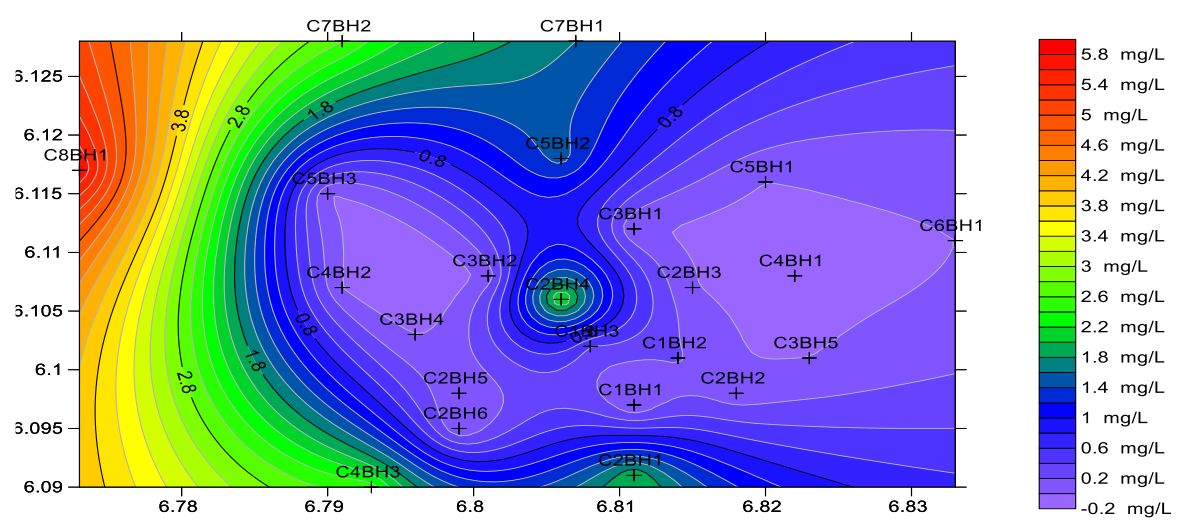

Figure 13 (a):Contour map of Iron values in the study area 


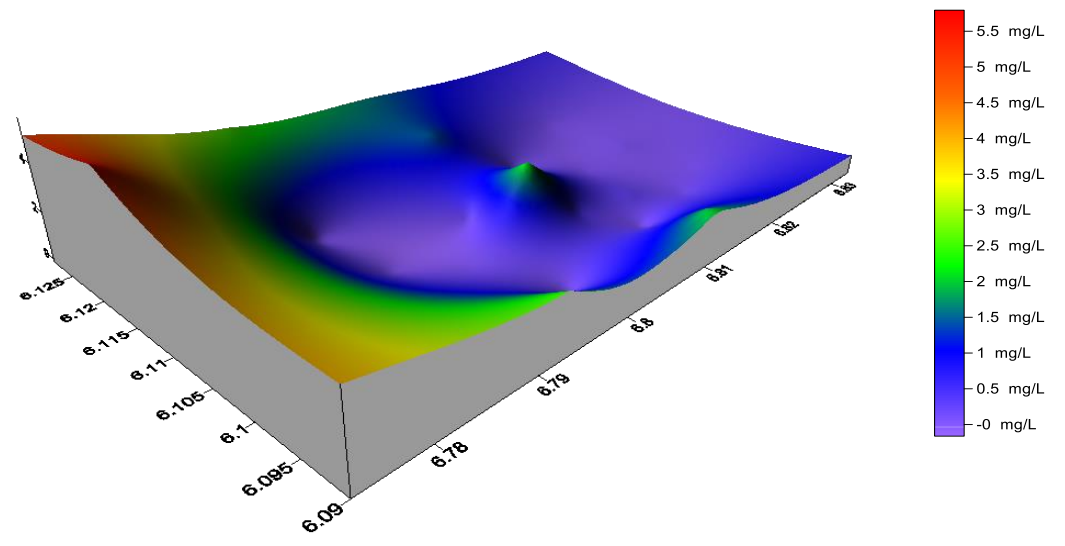

Figure 13 (b): 3-D model of Iron values in the study area

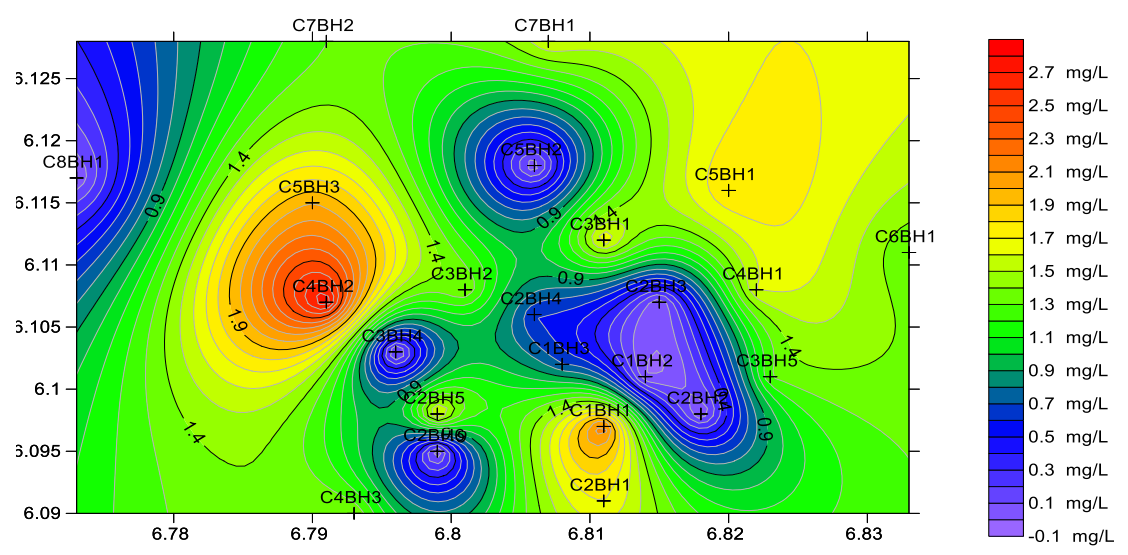

Figure 14 (a):Contour map of Mercury values in the study area
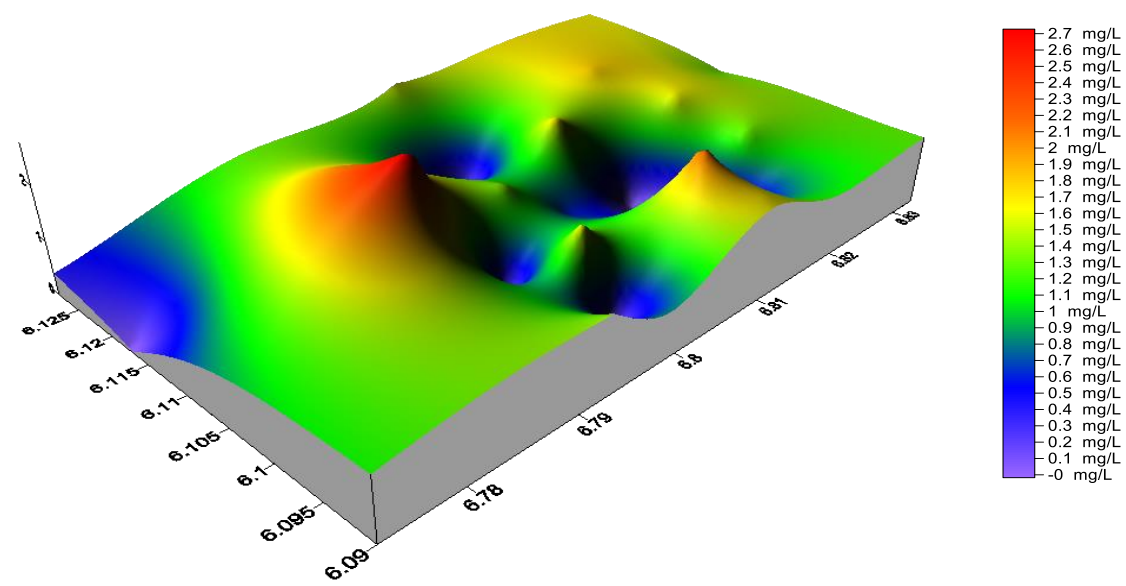

Figure 14 (b):3-D model of Mercury values in the study area 


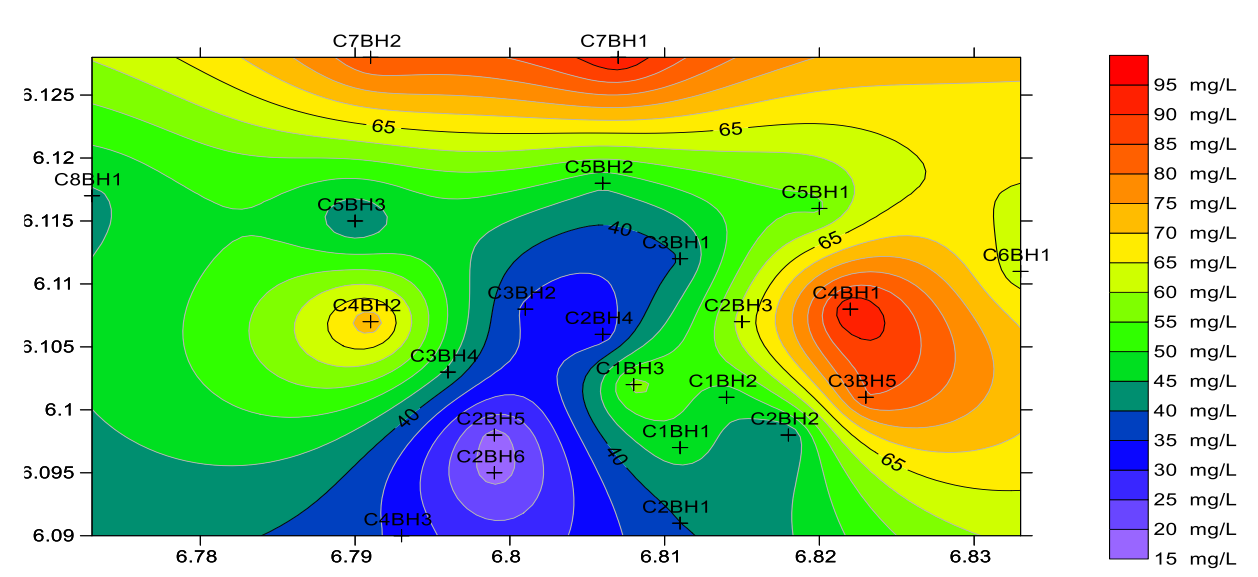

Figure 15 (a):Contour map of Bi-carbonate ion values in the study area

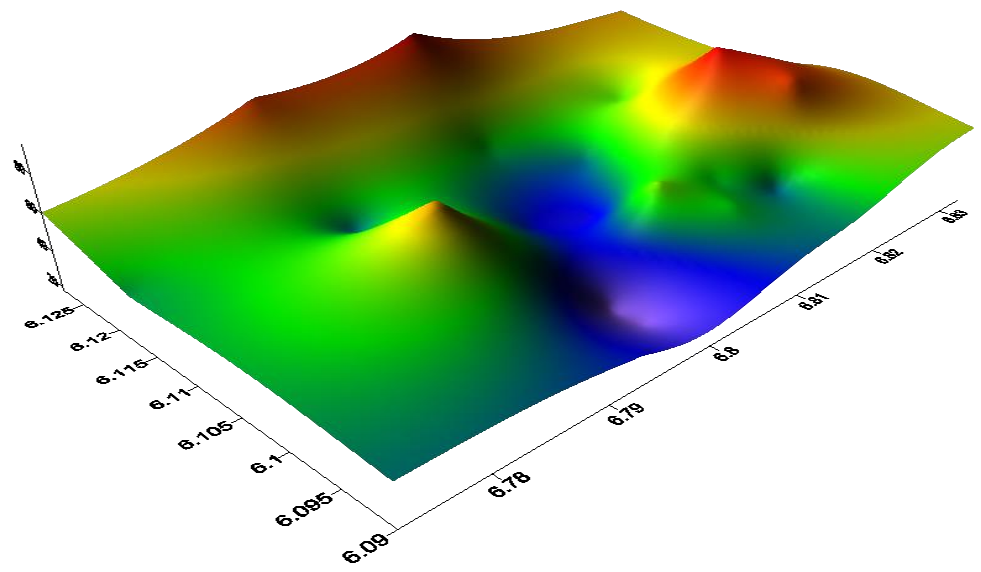

Figure 15 (b): 3-D model of Bi-carbonate ion values in the study area

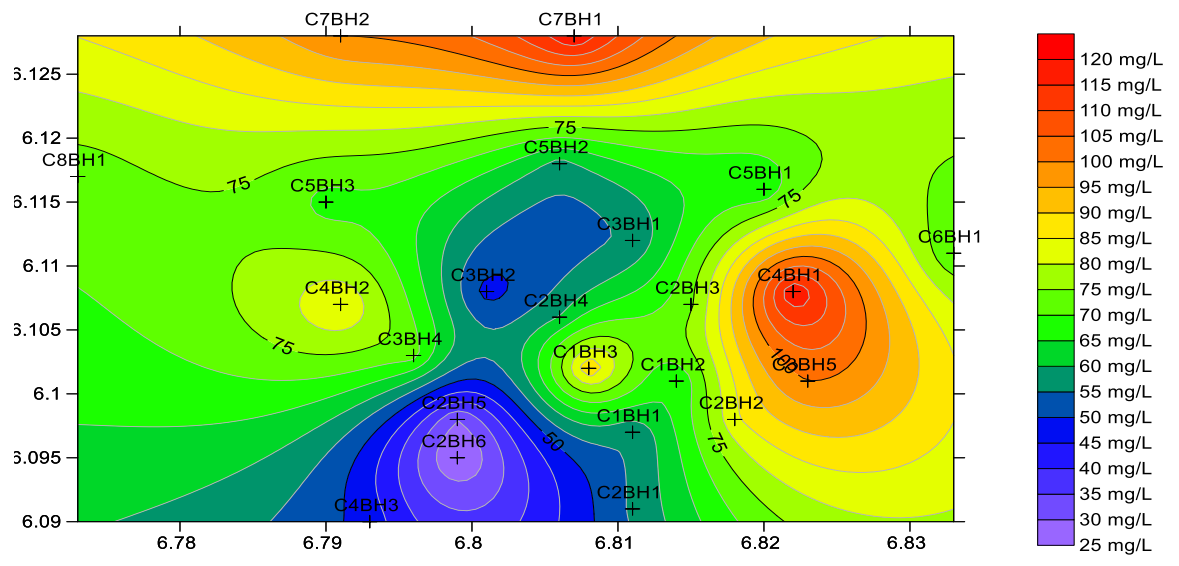

Figure 16 (a):Contour map of Carbonate ion values in the study area 


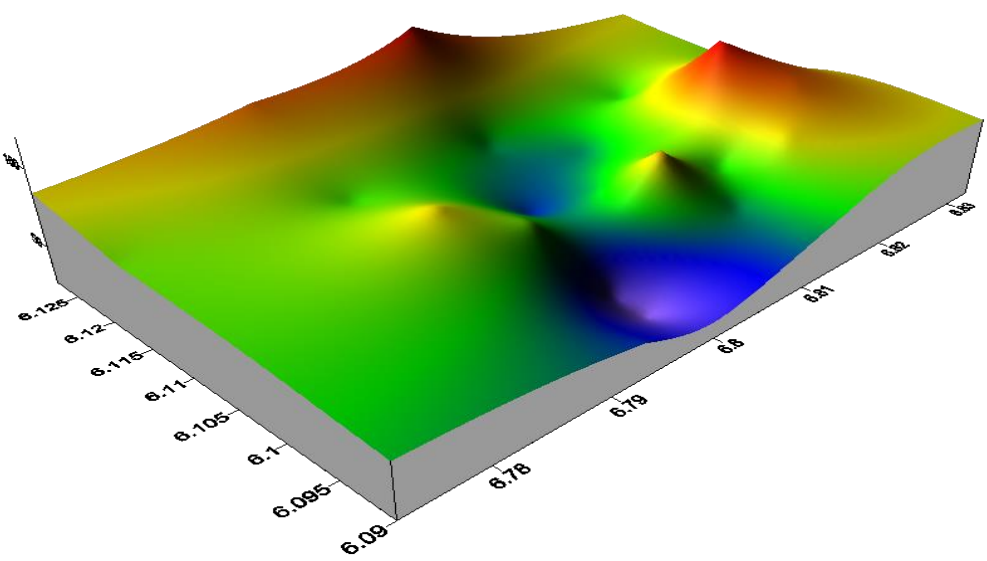

Figure 16 (b):3-D model of Carbonate ion values in the study area

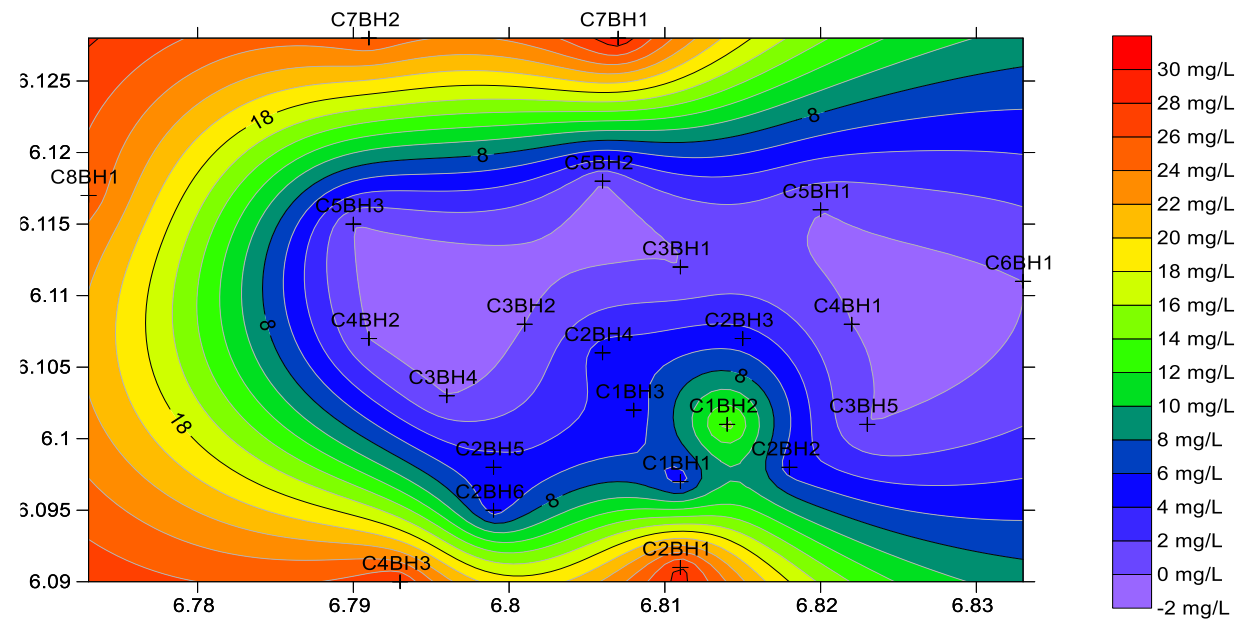

Figure 17 (a):Contour map of Sulfate ion values in the study area
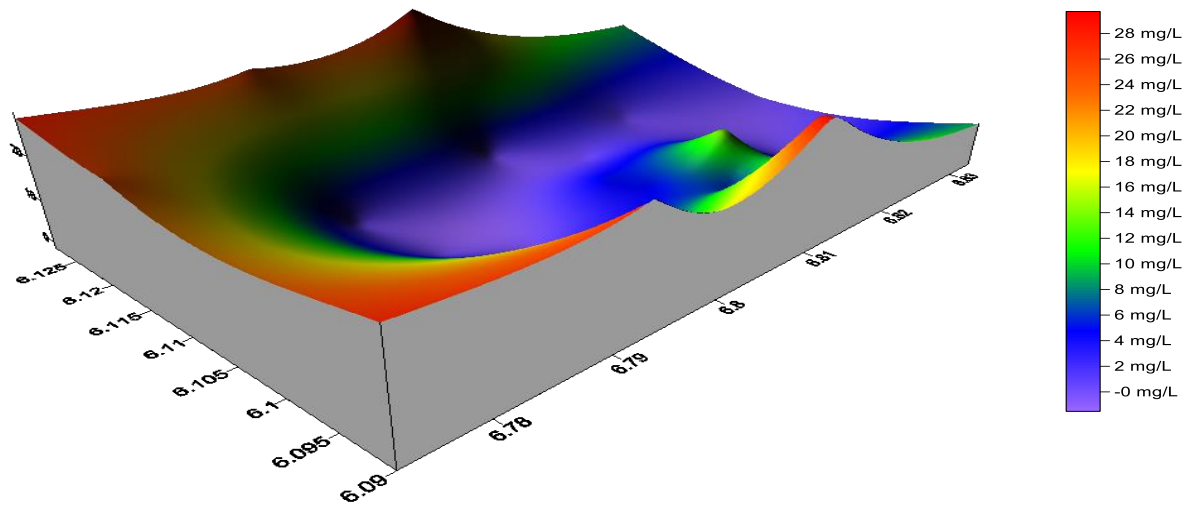

Figure 17 (b):3-D model of Sulfate ion values in the study area 


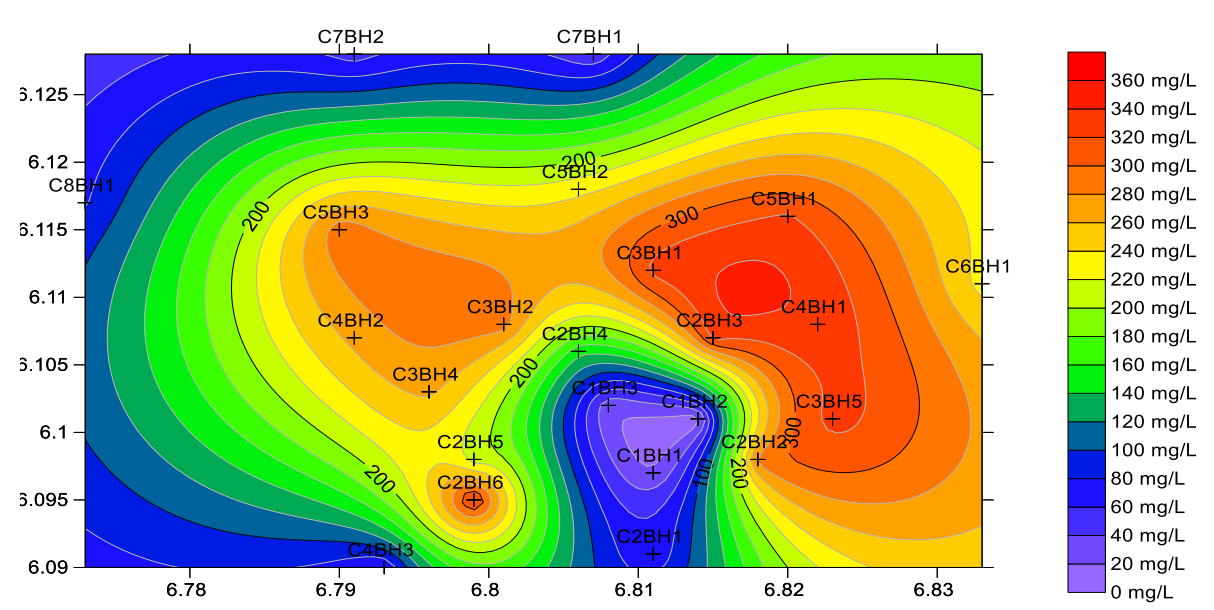

Figure 18 (a):Contour map of Nitrate values in the study area

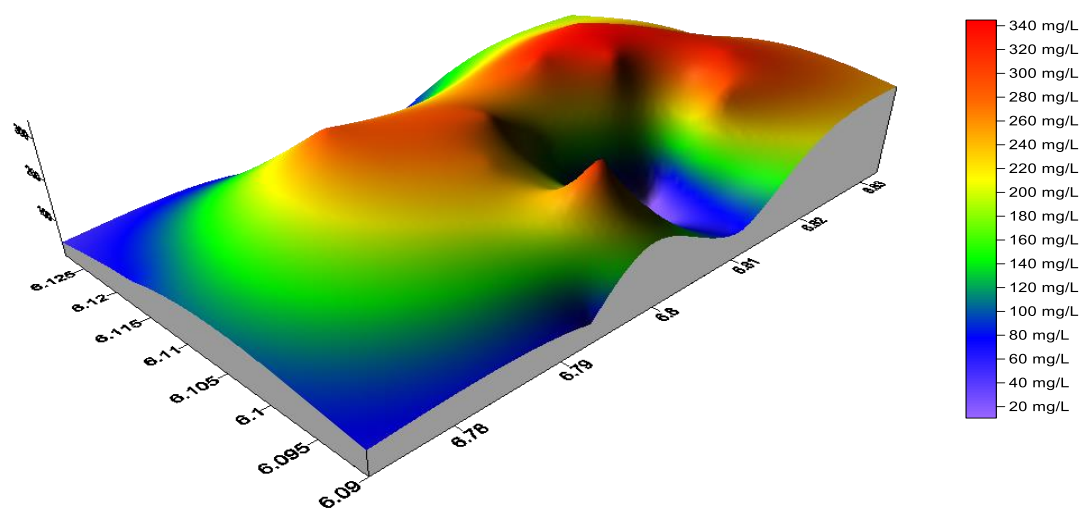

Figure 18 (b):3-D model of Nitrate values in the study area

\subsubsection{Bacteriological Characteristics of Groundwater and Leachate Samples:}

Most of the water samples contain significant amount of organic matter that provides nutrition for the growth and multiplication of micro-organisms. The total coliform count for all the water samples ranged between 3 to 19 cfu with the highest level recorded in $\mathrm{C} 1$. The faecal coliform count in all the water samples are below $3 \mathrm{cfu}$ whereas there was the presence of faecal streptococci in all the water samples with the highest count of $18 \mathrm{cfu}$ in $\mathrm{C} 3$. These results indicate that most of the water samples contain microorganisms that indicates groundwater contamination[3].

\section{CONCLUSION AND RECOMMENDATION}

The results obtained from this research indicated that the leachate generated from the waste dump site could have contaminant risks on boreholes located proximal to the waste dump. It is therefore recommended that a contaminant migration mitigation measure should be performed to reduce the risk of groundwater contamination in the study area and prior attention should be 
given to the problem of open waste dumping, with regard to public health and pollution risks. The operation of the Obosi dumping site must be stopped as soon as possible so as to avoid groundwater and public health problems while a temporary disposal options should be considered which should be free of environmental pollution and public health risks. Furthermore, engineered landfills should be constructed with adequate provisions for proper collection and treatment of leachate.

\section{REFERENCES}

1. Alcamo, S. Fundamentals of Microbiology, 2001, Sixth Edition, ISBN: 0 - 7637- 1236-1.

2. Al-Khadi S. Assessment of groundwater contamination vulnerability in the vicinity of Abqaiq landfill: A GIS approach.(Doctoral dissertation, King Fahd University of Petroleum and Minerals, Saudi Arabia, 2006, 106-215.

3. American Public Health Association, (APHA).Standard methods for the examination of water and wastewater, 1992, 19th edition, Washington.

4. Assem, L. \& Zhu, H. Chromium - Toxicological overview. Institute of Environment and Health, Cranfield University, 2007, 1, 14.

5. Badiye, A. , Kapoor N. \& Khajuria H. Copper toxicity: A comprehensive study .Research Journal of Recent Sciences, 2013,2, 58-67.

6. Bagchi, A. C. Design of landfills and integrated soil waste management in landfill design, 2004,( 3rd ed., p. 696). John Willey and Sons, USA.

7. Bhalla, B.,Sainib M. S. \&Jha M. K. Assessment of groundwater contamination near unlined municipal solid waste landfill site. International Journal of Chemical and Environmental Engineering, 2013, 4(5), 301-310.

8. Carroll, D. Rainwater as a chemical agent of geologic processes: A review, U.S. Geological Survey Water - Supply, 1962, Paper 1535 - G, 18.

9. Christensen, T. H., Kjeldsen, P., BBjerg, P. L., Jensen, D. L., Christensen, J. B., \&Baun, A. Applied Geochemistry, 2001,16, 659-718.

10. Cointreau, S. J. (1982).A project guide, Urban Development Departmentt, World Bank, 1982.

11. Doan, P. L. Habitat International, 1998, 22(1), 27-39.

12. Futta, D., Yoscos, C., Haralambous, K. J. \&Loizidou, M. An assessment of the effect of landfill leachate on groundwater quality, 1997.

13. Gaikwad, R.W., Sapkal, V. S. \&Sapkal, R. S. Acid mine drainage: A water pollution issue in mining industry. International Journal of Advanced Engineering Technology, 2011, 2(4), 257-262. 
14. Gharaibeh, S. H. \&Masad, A.Die Problomatite der Ahallbeseitingung in Jordan.Fallstudie Fur Enstasicklungs lander. Wasser und Boden,1989, 10: 620-62.

15. Lee, G. F. \& Jones-Lee, A .Report to the CA/NV AWWA Section Source Water Quality Committee, 1993, 8 p.

16. Lievremont, D.,Bertin P. N. \& Lett, M. Arsenic in contaminated waters: Biogeochemical cycle, microbial metabolism and biotreatment processes. Elsevier, Biochimie,2009, 91,12291237

17. Longe, E.O., Enekwechi L.O. Investigation on potential groundwater impacts and influence of local hydrogeology on natural attenuation of leachate at a municipal landfill. International Journal of Environmental Science and Technology, 2007,4(1), 133-140.

18. Lone, T. H., Kumar, A., Khan, F., Saxena, S. \& Dar, A. I. Evaluating the effect of landfill leachate on groundwater quality in relation to physicochemical and bacteriological characteristics. Journal of Chemical and Pharmaceutical Research, 2012, 4(12), 5202-5214.

19. Martine, V. Environmental Health perspective supliments.2000, 108(1).

20. Mor, S., Ravindra, K., Dahiya, R. P. \& Chandra, A. Leachate characterization and assessment of groundwater pollution near municipal solid waste landfill site. Environmental Monitoring Assessment, 2006, 4, 325-334.

21. Nigerian Standard for Drinking Water (NIS). Approved by SON Governing Council. Abuja/Lagos HQ. 2007, pp 5.

22. Pohland, F. G. \& Harper S. R. US Environmental Protection Agency, Cincinnati,1985, EPA/600/2-86/073.

23. Pohland, F. G., Harper, S. R., Chang, K. C., Dertien, J. T. \&Chian, E.S.K. Water Pollution Resources Juornal, Canada,1985, 20(3): 10-24.

24. Sawyer, C. N. \& Mc-Carty, P.L. (Ed.). Chemistry for Sanitary Engineers. McGraw Hill, New York, U.S.A, 1967.

25. Self, J. R \& Waskom, R.M. Nitrate in drinking water. Colorado: Colorado State University, U.S. Department of Agriculture and Colorado counties cooperating, 2013.

26. Shankar, B. S., Balasubramanya, N. \&Maurthesha, T. M. Environmental Monitoring and Assassment, 2007, 142(3).

27. Sing, G. \&Rezal, R. Solid Waste Management-Current Status and Strategies for the Future. Journal of American Science, 2002, 5(5), 53-58.

28. United States Environmental Protection Agency (USEPA). Municipal solid waste generation, recycling and disposal in the United States: Facts and figures for 2007, EPA-530-F08-018, 2008, 12 pp. 
29. Wilcox, L. V. Classification and use of irrigation waters, Washington: US Department of Agriculture, 1995, pp 19.

30. World Health Organization, (WHO). Guidelines for Drinking Water Quality. Geneva, 2nd Ed., 1999, 97- 100.

31. Wuana, R. A. \& Okieimen, F. E. Heavy metals in contaminated soils: A review of sources, chemistry, risks and best available strategies for remediation. International Scholarly Research Notices, Article ID 402647, 2011, pp. 20. 